\title{
Viral suppressors from members of the family Closteroviridae combating antiviral RNA silencing: a tale of a sophisticated arms race in host-pathogen interactions
}

\author{
Muhammad Dilshad Hussain ${ }^{1}$, Tahir Farooq ${ }^{2}$, Xi Chen $^{1}$, Muhammad Tariqjaveed ${ }^{3}$, Tong Jiang ${ }^{1}$, Sijia Liu ${ }^{1}$ and \\ Tao Zhou ${ }^{1 *}$ (1)
}

\begin{abstract}
RNA silencing is an evolutionarily homology-based gene inactivation mechanism and plays critical roles in plant immune responses to acute or chronic virus infections, which often pose serious threats to agricultural productions. Plant antiviral immunity is triggered by virus-derived small interfering RNAs (vsiRNAs) and functions to suppress virus further replication via a sequence-specific degradation manner. Through plant-virus arms races, many viruses have evolved specific protein(s), known as viral suppressors of RNA silencing (VSRs), to combat plant antiviral responses. Numerous reports have shown that VSRs can efficiently curb plant antiviral defense response via interaction with specific component(s) involved in the plant RNA silencing machinery. Members in the family Closteroviridae (closterovirids) are also known to encode VSRs to ensure their infections in plants. In this review, we will focus on the plant antiviral RNA silencing strategies, and the most recent developments on the multifunctional VSRs encoded by closterovirids. Additionally, we will highlight the molecular characters of phylogenetically-associated closterovirids, the interactions of these viruses with their host plants and transmission vectors, and epidemiology.
\end{abstract}

Keywords: Closterovirids, Antiviral RNA silencing, Viral pathogenicity, Plant immunity, Crop disease

\section{Background}

The viruses of the family Closteroviridae are characterized by their flexuous, exceptionally long filamentous, and non-enveloped particles with lengths of $950-2200 \mathrm{~nm}$ and diameters of $10-13 \mathrm{~nm}$. These closterovirids are composed of positive-sense single-stranded RNA (+ssRNA), causing acute or chronic infections in plants and threatening agricultural production systems globally (Martelli 2019; Jones 2021). Generally,

\footnotetext{
*Correspondence: taozhoucau@cau.edu.cn

1 State Key Laboratory for Agro-Biotechnology, and Ministry of Agriculture and Rural Affairs, Key Laboratory for Pest Monitoring and Green

Management, Department of Plant Pathology, China Agricultural University, Beijing 100193, China
}

Full list of author information is available at the end of the article closterovirids have a common pattern of genomic organization that possesses variable numbers of open reading frames (ORFs). However, the presence of cellular heat-shock proteins HSP70 homology (HSP70h) with a duplicated and deviated form of coat protein (designated as minor coat protein or $\mathrm{CPm}$ ) in genome are hallmarks of viruses in this family, distinguishing them from other plant viruses (Agranovsky 2016; Ruiz et al. 2018). Strikingly, their genomic expression strategy is predicated according to the proteolytic processing, such as $a+1$ translational/ribosomal frameshifting together with subgenomic mRNAs. Therefore, strong negative selection and recombination are primary factors influencing their genetic diversity (Rubio et al. 2013; Fuchs et al. 2020). original author(s) and the source, provide a link to the Creative Commons licence, and indicate if changes were made. The images or other third party material in this article are included in the article's Creative Commons licence, unless indicated otherwise in a credit line to the material. If material is not included in the article's Creative Commons licence and your intended use is not permitted by statutory regulation or exceeds the permitted use, you will need to obtain permission directly from the copyright holder. To view a copy of this licence, visit http://creativecommons.org/licenses/by/4.0/. 
Presently, according to the 2020 master species list-36 (MSL36) released by the International Committee on Taxonomy of Viruses (ICTV), the Closteroviridae family contains 4 genera (Amplelovirus, Crinivirus, Closterovirus and Velavirus) and 52 identified species, with 7 unassigned species (https://ictv.global/taxonomy). Most closterovirids have evolved from common ancestors and are transmitted through specific insect vectors (arthropods), such as mealybugs (Ampelovirus), aphids (Closterovirus), and whiteflies (Crinivirus). The vector for members of the genus Velarivirus is yet to be identified. However, there is merely an exception for mint vein banding-associated virus (MVBaV). MVBaV is an aphid-borne virus, which is phylogenetically distant from other members of the family (Martelli et al. 2012; Fuchs et al. 2020). The majority of closterovirids cause substantial disease epidemics in combined infections with other plant viruses that may result in synergistic effects. Moreover, the host range and environmental factors determining vector population dynamics have important epidemiological consequences (Tzanetakis et al. 2007, 2013; Quito-Avila et al. 2014).

To improve crop quality and quantity, a study of the progress of viral infection and defense strategies remains most significant. It is obvious from molecular characterization of plant viruses that virus infection process is coordinated with their restricted viral factors, through which viruses interact with host proteins and recruit biological processes crucial for their multiplication and translocation (Tatineni et al. 2012; Castillo-Gonzalez et al. 2015; Liu et al. 2021). On the other hand, plants develop a set of complex antiviral defense system to counter viral infection, including antiviral RNA silencing, systemic acquired resistance (SAR), hypersensitive responses (HR), DNA methylation, ubiquitin-proteasome system (UPS), and hormone signaling pathways such as salicylic acid (SA), jasmonic acid (JA), and ethylene (ET) (Huh et al. 2012; Mandadi and Scholthof 2013; Balint-Kurti 2019; Li and Wang 2019; Tirnaz and Batley 2019; Kamle et al. 2020; Dubiella and Serrano 2021; Zhao and Li 2021).

Recently, significant research has been done to understand the mechanisms and functions of antiviral RNA silencing as well as viral strategies to counter this defense (Jones and Dangl 2006; Shi et al. 2008; Sansregret et al. 2013; Csorba et al. 2015; Jin et al. 2021; Teixeira et al. 2021). Antiviral RNA silencing is a highly conserved regulatory mechanism of gene expression, which plays the most important role in different biological processes associated with host protection against viral infection. Plants recruit this mechanism as a shield against viruses by encoding abundant crucial components, such as RNA-dependent RNA polymerases (RdRps), Dicer ribonucleases (DCLs), Argonaute endonucleases (AGO), double-stranded RNA (dsRNA), and helicases (Lee and Carroll 2018; Muhammad et al. 2019; Lax et al. 2020). In response to this defense strategy, viruses have also evolved to produce various multifunctional proteins that act as VSRs to avoid being silenced and thus ensure successful infections (Daròs 2017; Gaffar and Koch 2019).

Our current review highlights recent progress and breakthroughs in plant-targeting VSRs together with particular strategies and mechanisms aimed at evading antiviral RNA silencing. It also demonstrates mechanistic insights into various VSR strategies by which closterovirids evade antiviral responses of host plants in order to execute successful viral infections. Closterovirids are presented here according to their evolutionary relatedness (Fig. 1) as members of each genus tend to have similar genomic organization, transmission vectors, and host ranges, but diverse modes of infection (Table 1).

\section{Antiviral RNA silencing and plant immunity}

Plants and microbial pathogens are fascinatingly engaged in a continuous battle for survival. Plant immunity to non-viral pathogens has revealed well-organized, multilayered, and sophisticated signaling pathways, which are triggered by the perception of diverse pathogen-associated molecular patterns (PAMPs) to initiate the first layer of defense. This fundamental defense mechanism (PAMP-triggered immunity, PTI) elucidates the entire co-evolutionary arms race between pathogen and host plant. For invading pathogens, they encode virulence factors, named as effectors, to suppress PTI (Shan et al. 2008; Calil and Fontes 2017; Gouveia et al. 2017; Teixeira et al. 2021). Therefore, plants respond to PTI suppression through resistance $(\mathrm{R})$ proteins using a highly precise and effective type of immunity, known as effector-triggered immunity (ETI) (Cui et al. 2015; Hatsugai et al. 2017; Peng et al. 2018). Since this phenomenon represents protein-based rather than RNA-involved defense mechanisms, it was considered that PTI and ETI are remarkably independent of antiviral RNA silencing. The mechanism of antiviral RNA silencing in plants reveals a related process, termed as post-transcriptional gene silencing (PTGS). Recently, biological evidences have indicated that PTGS and transcriptional gene silencing (TGS), induced by endogenic small RNAs (sRNAs), are evolving as significantly crucial drivers of ETI and PTI signaling pathways, as well as R gene expression (Zhai et al. 2011; Baltusnikas et al. 2018; Tan et al. 2020; Sanan-Mishra et al. 2021). Furthermore, several classes of microorganisms, such as plant viruses, bacteria, and oomycetes, have been discovered to produce suppressor proteins as part of their virulence effectors, to suppress RNA silencing in host plants and cause disease (Navarro et al. 2008; He et al. 2019). 


\section{The mechanism and localization of antiviral RNA silencing}

In plants, an antiviral silencing pathway is triggered by two discrete classes of sRNAs, including microRNAs (miRNAs) and small interfering RNAs (siRNAs), exerting diverse actions such as mRNA degradation, DNA methylation, and translational inhibition (Li and Wang 2019; Tan et al. 2020). Mechanistically, the antiviral RNA silencing model is divided into initiation, effector, and amplification phases (Zhang et al. 2015; Csorba and Burgyán 2016). Plant viruses, containing RNA genomes with defective regulatory stem-loop, are transcribed into complementary dsRNA replication intermediates through viral encoded RdRps. This dsRNA is designed as a virus-associated molecular pattern (VAMP), which is a form of PAMP. During the initiation phase, VAMPs are recognized and cleaved by dsRNA-specific RNases named as DCL enzymes (primarily by DCL4 and secondarily by DCL2), producing 21 to 24-nt doublestranded vsiRNA duplexes (Pumplin and Voinnet 2013). On the other hand, microRNA (MIR) genes encode pre-miRNAs, which are transcribed into primary miRNAs (pri-miRNAs) through RNA polymerase II (Pol II). Subsequently, stem-loop containing pri-miRNAs are processed into mature miRNA duplexes through the RNA III family enzyme DCL1. These miRNA and vsiRNA duplexes are stabilized at their $3^{\prime}$ end, mediated by the HUA Enhancer 1 (HEN1)-dependent methylation process (Burgyan and Havelda 2011; Rogers and Chen 2013; Zhang et al. 2015). Furthermore, stabilized vsiRNA and miRNA duplexes were unzipped and separated into two strands, termed as guide and passenger strand, respectively, by helicase. The guide strand is incorporated into AGO proteins, facilitating the formation of a complex (RNA-induced silencing complex, RISC), while the passenger strand is shattered (Vaucheret 2008; Zhang et al. 2015; Waheed et al. 2021). To complete the effector phase of antiviral RNA silencing, RISCs target vsiRNA or miRNA complementary mRNAs and trigger their PTGS via endonucleolytic cleavage or translational inhibition (Waterhouse and Helliwell 2003; Brodersen et al. 2008; Carbonell and Carrington 2015; Mengistu and Tenkegna 2021). For the amplification of antiviral RNA silencing, AGOsliced products serve as templates for RdRp (RDR for cellular RdRps) complexes using RNA-helicases (SGS3 and SDE5), the cofactors of RDR-mediated pathways (Vaucheret 2006; Jauvion et al. 2010; Csorba et al. 2015; Tong et al. 2021).

In plant, antiviral RNA silencing spreads between adjacent cells and over long distances via plasmodesmata and phloem, respectively. In local spread of RNA silencing, most probably, silencing molecules (siRNAs, miRNAs) move beyond the production sites to 10-15 cells. However, the activation of local silencing signaling is independent of homologous transcripts. The activity of RDR6 and SDE3 is not essential for the synthesis or detection of silencing signals, but at least three SILENCING MOVEMENT DEFICIENT genes (SMD1-3) are mandatory for cell-to-cell movements (Voinnet 2005; Mermigka et al. 2016). Meanwhile, in the particular scenario of systemic spread of silencing, the amplification process requires RDR6, SDE3 or SDE5 to convert homologous transcripts into new dsRNAs in

\footnotetext{
(See figure on next page.)

Fig. 1 A phylogenetic tree demonstrating the linkages between species and genera within the family Closteroviridae on the basis of the amino acids sequence of RdRp. A multiple sequence alignment of RdRp amino acids sequence was performed using CLUSTALW. A phylogenetic tree was constructed with MEGA7 software using the neighbor-joining method and bootstrapped 1000 times. The numbers on nodes particularly signify bootstrapped confidence percentages. The abbreviations and accession numbers of closterovirids involved in this tree: Actinidia virus 1 (AcV-1;YP_009407919.1); Air potato virus 1 (AiPoV-1; AZB50207.1); Areca palm velarivirus 1 (APV-1;YP_009140432.1); Bean yellow disorder virus (BnYDV; YP_001816770.1); Beet pseudo yellows virus (BPYV; NP_940796.1); Blueberry virus A (BVA; YP_006638806.1); Blackberry vein banding-associated virus (BVBaV; YP_008411010.1); Beet yellow stunt virus (BYSV; AAC55659.2); Beet yellows virus (BYV; AAF14300.1); Blackberry yellow vein-associated virus (BYVaV; YP_227378.1); Cucurbit chlorotic yellows virus (CCYV; AFN61343.1); Cordyline virus 1 (CoV-1; YP_009506344.1); Cordyline virus 2 (CoV-2; AFJ05046.1); Cordyline virus 3 (CoV-3; AFJ05056.2); Cordyline virus 4 (CoV-4; AFJ05062.2); Carnation necrotic fleck virus (CNFV; YP_009506332.1); Citrus tristeza virus (CTV; ANA04448.1); Carrot yellow leaf virus (CYLV; YP_003075965.1); Cucurbit yellow stunting disorder virus (CYSDV; AAM73639.2); Diodia vein chlorosis virus (DVCV; YP_009507950.1); Grapevine leafroll-associated virus 1 (GLRaV-1;YP_004940642.1); Grapevine leafroll-associated virus 2 (GLRaV-2; AFV34734.1); Grapevine leafroll-associated virus 3 (GLRaV-3; AXI81954.1); Grapevine leafroll-associated virus 4 (GLRaV-4; AKB90851.1); Grapevine leafroll-associated virus 7 (GLRaV-7; YP_004935919.1); Grapevine leafroll-associated virus 13 (GLRaV-13; BAU68561.1); Little cherry virus 1 (LChV-1; AXN70106.1); Little cherry virus 2 (LChV-2; AAM96221.1); Lettuce chlorosis virus (LCV; AST35785.1); Lettuce infectious yellows virus (LIYV; AAA61798.1); Mint virus 1, (MV-1; YP_224091.1); Olive leaf yellowing-associated virus (OLYaV; CAD29306.1); Plum bark necrosis stem pitting-associated virus (PBNSPaV; AGL80631.1); Persimmon virus B (PeVB; YP_0091 12883.1); Pineapple mealybug wilt-associated virus 1 (PMWaV-1; ABR68934.1); Pineapple mealybug wilt-associated virus 2 (PMWaV-2; AAG13939.1); Pineapple mealybug wilt-associated virus 3 (PMWaV-3; ABD62348.1); Potato yellow vein virus (PYV; ASD49931.1); Raspberry leaf mottle virus (RLMoV; YP_874185.1); Rose leaf rosette-associated virus (RLRaV; YP_009058929.1); Strawberry chlorotic fleck-associated virus (SCFaV; YP_762622.1); Strawberry pallidosis-associated virus (SPaV; YP_003289291.1); Sweet potato chlorotic stunt virus (SPCSV; AEA92656.1); Tomato infectious chlorosis virus (TICV; YP_003204952.1); Tomato chlorosis virus (ToCV; YP_293695.1); Tobacco virus 1 (TV-1;YP_009162622.1); Tetterwort vein chlorosis virus (TVCV; YP_009507961.1)
} 


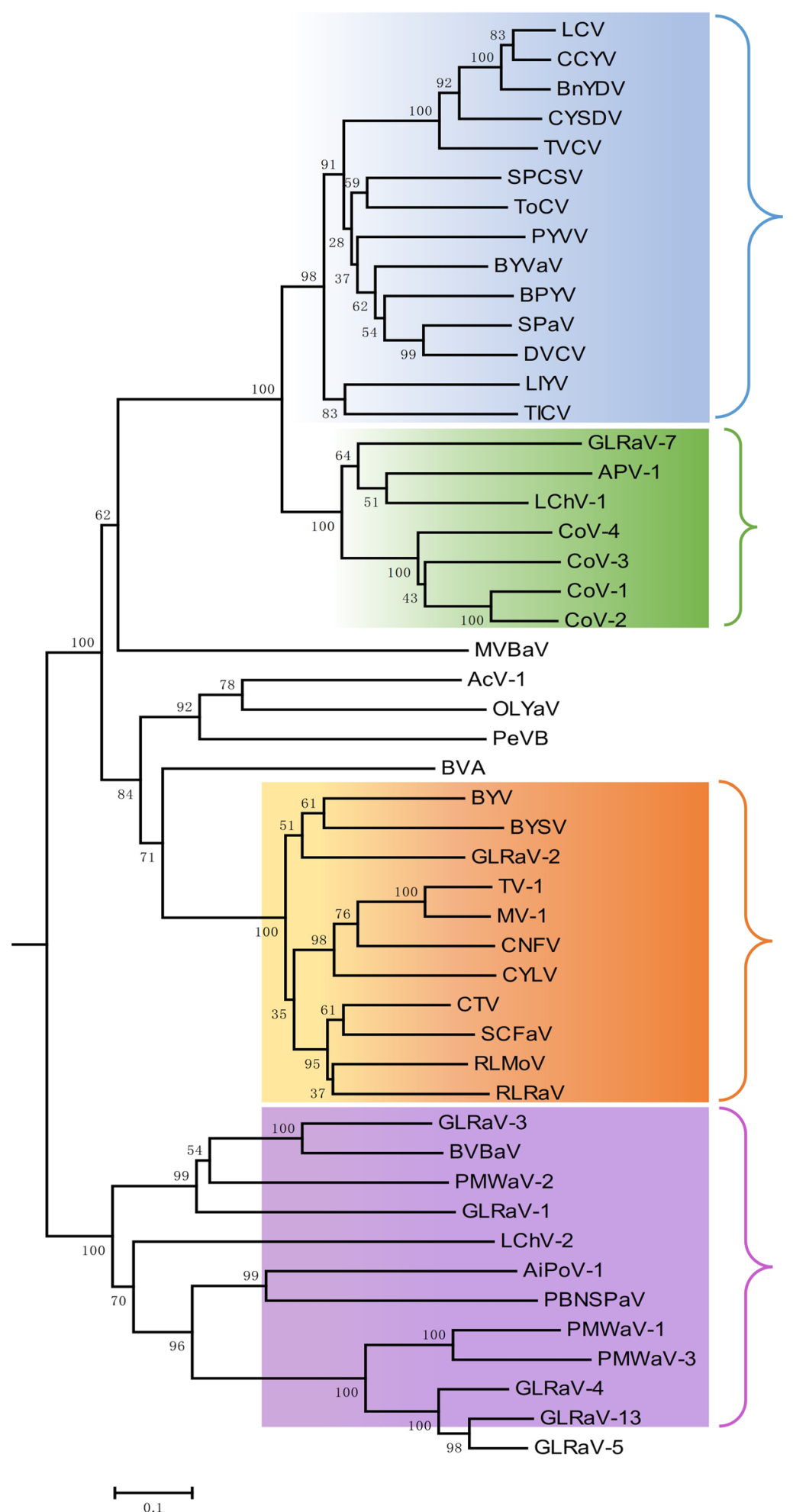

\section{Crinivirus}

Velarivirus

\section{Closterovirus}

\section{Ampelovirus}

Fig. 1 (See legend on previous page.) 


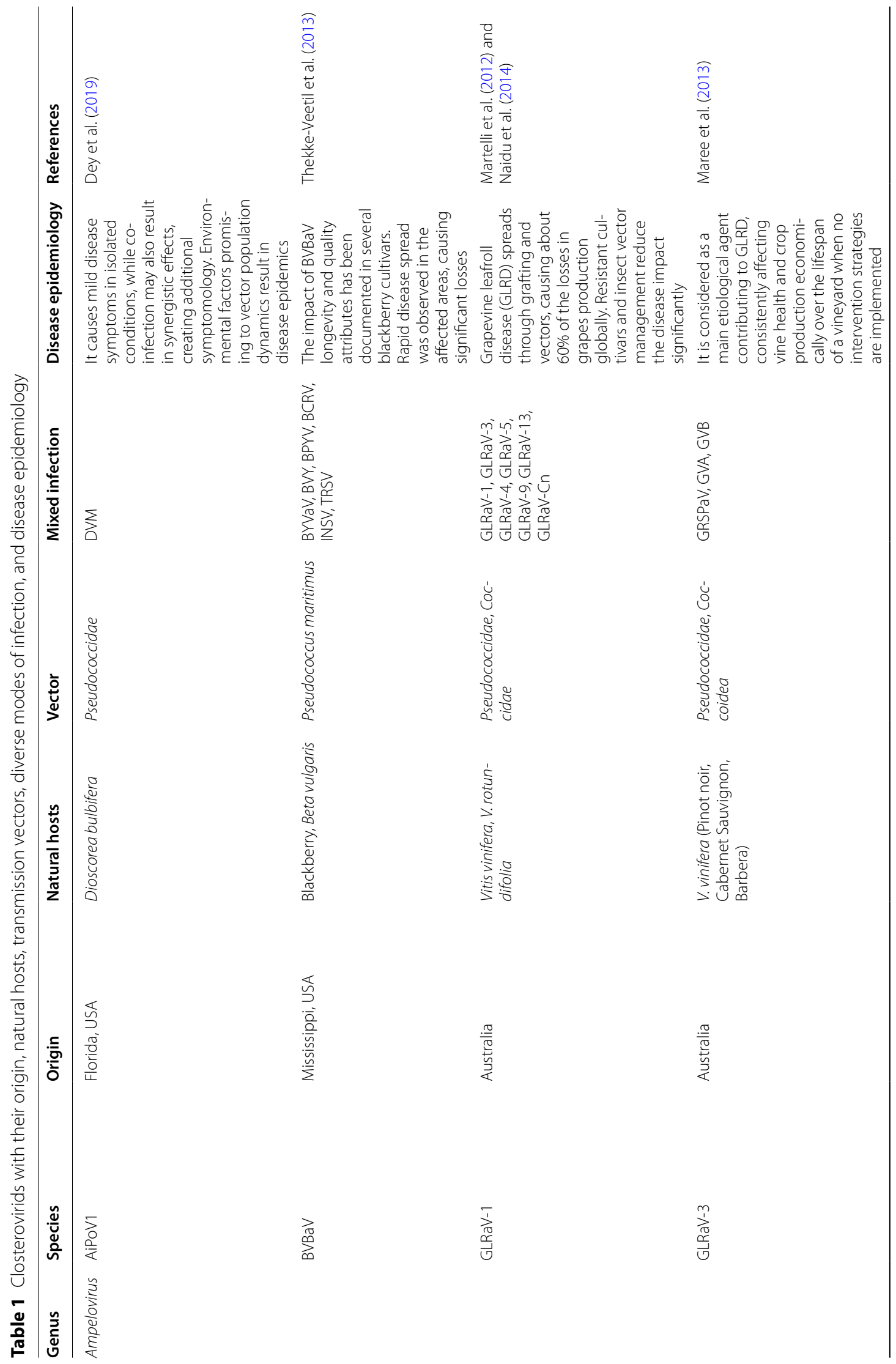




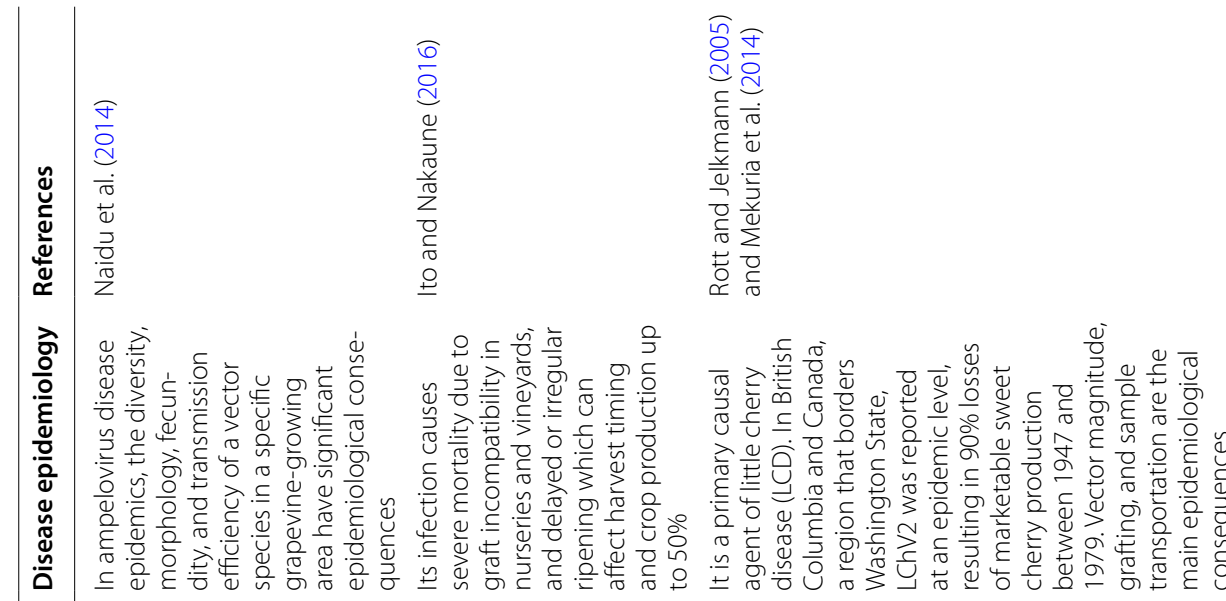

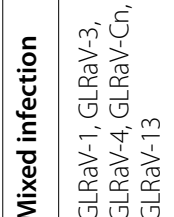

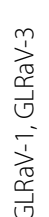

年

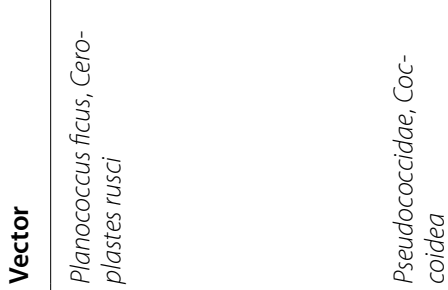

i

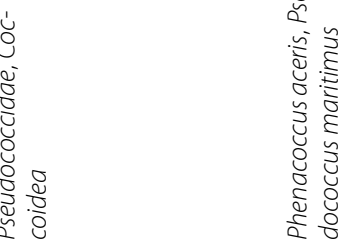




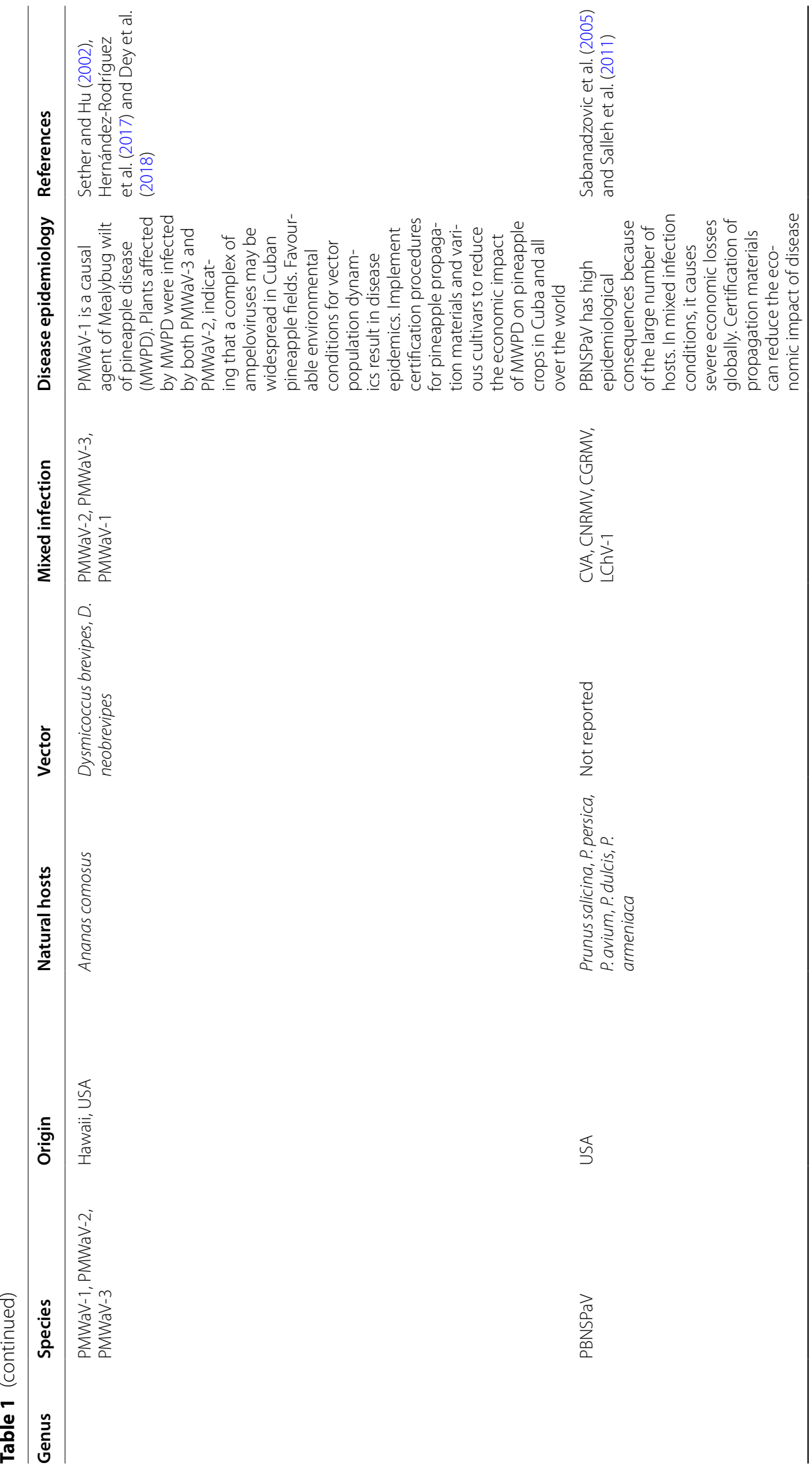




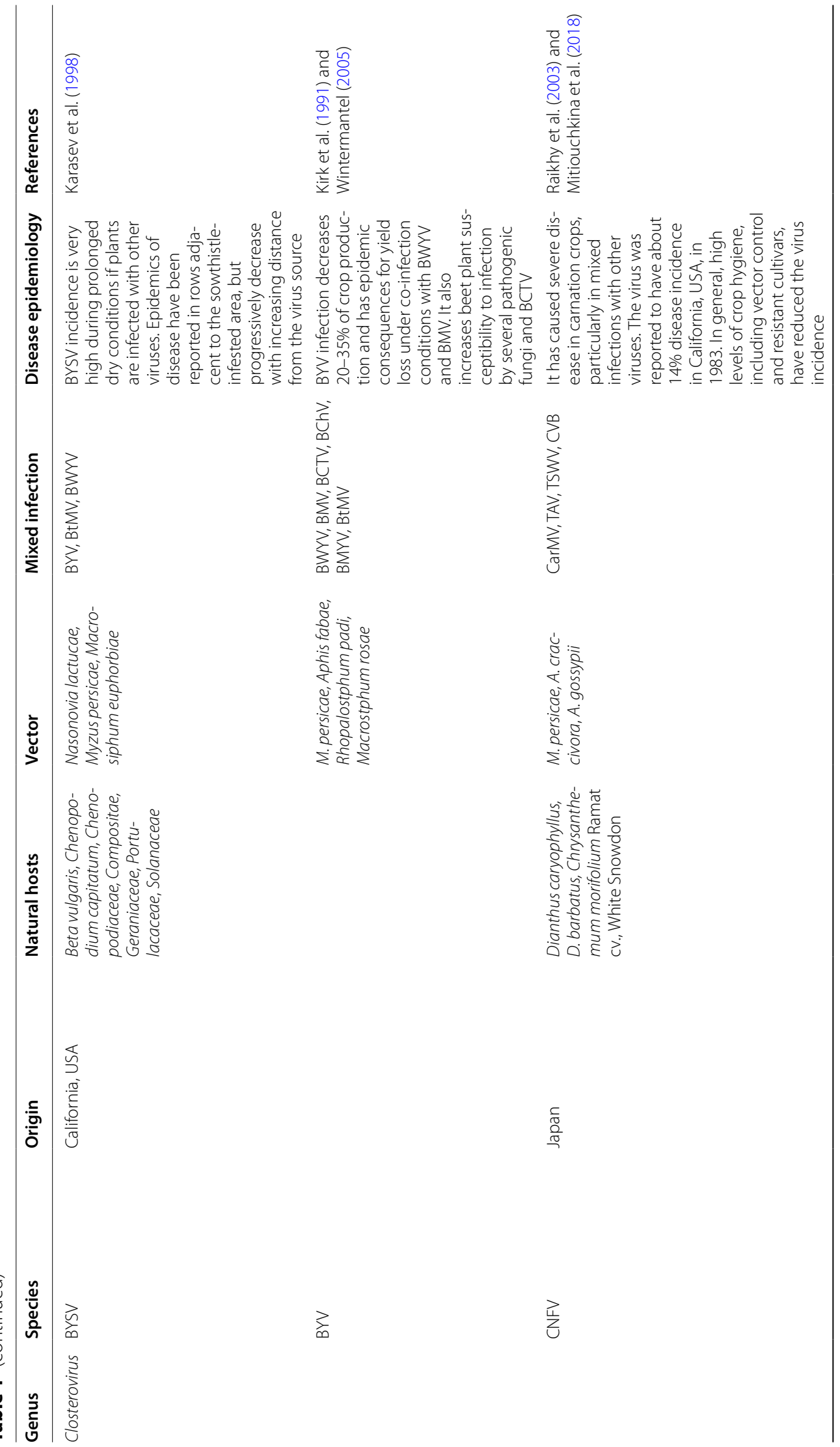




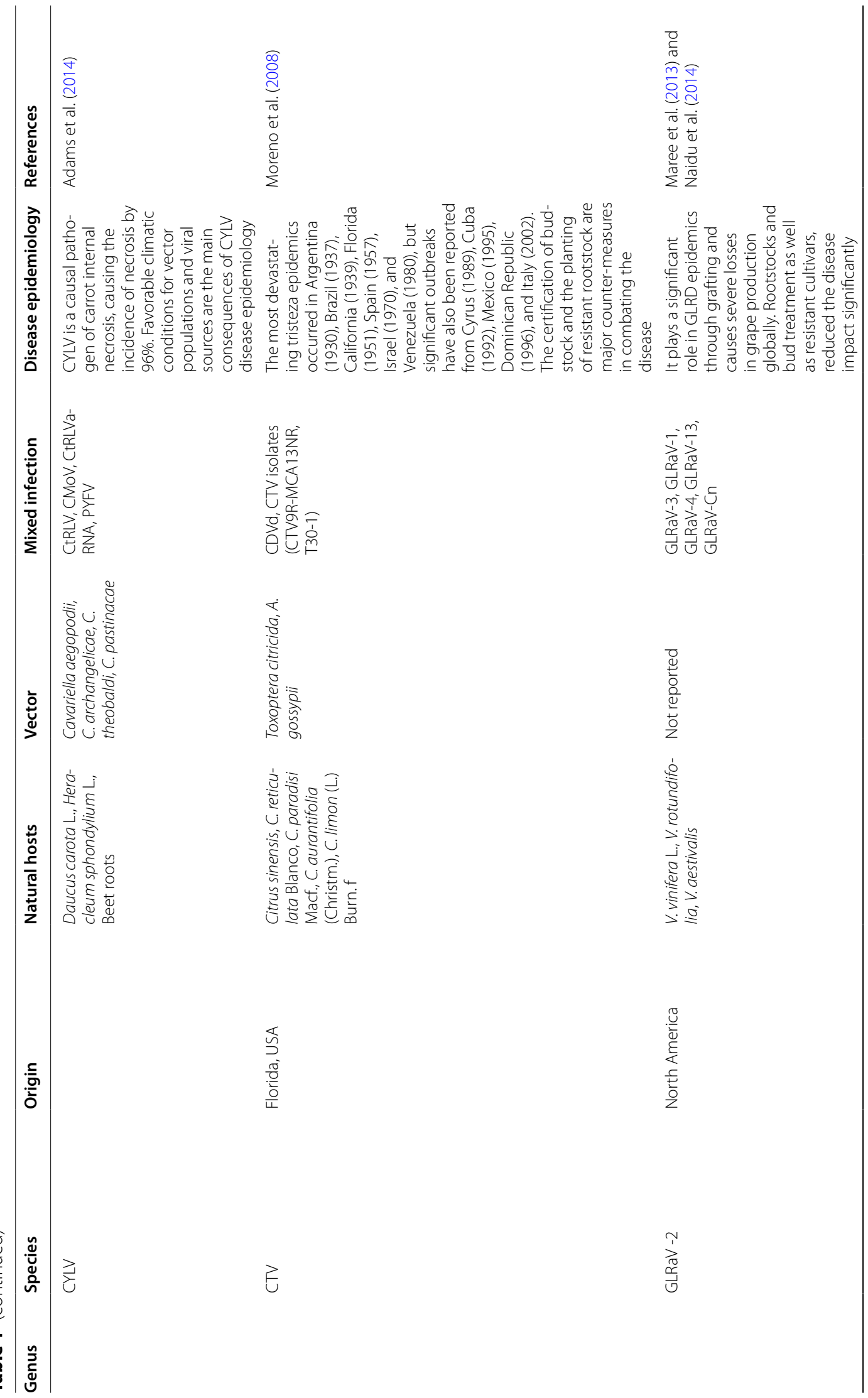




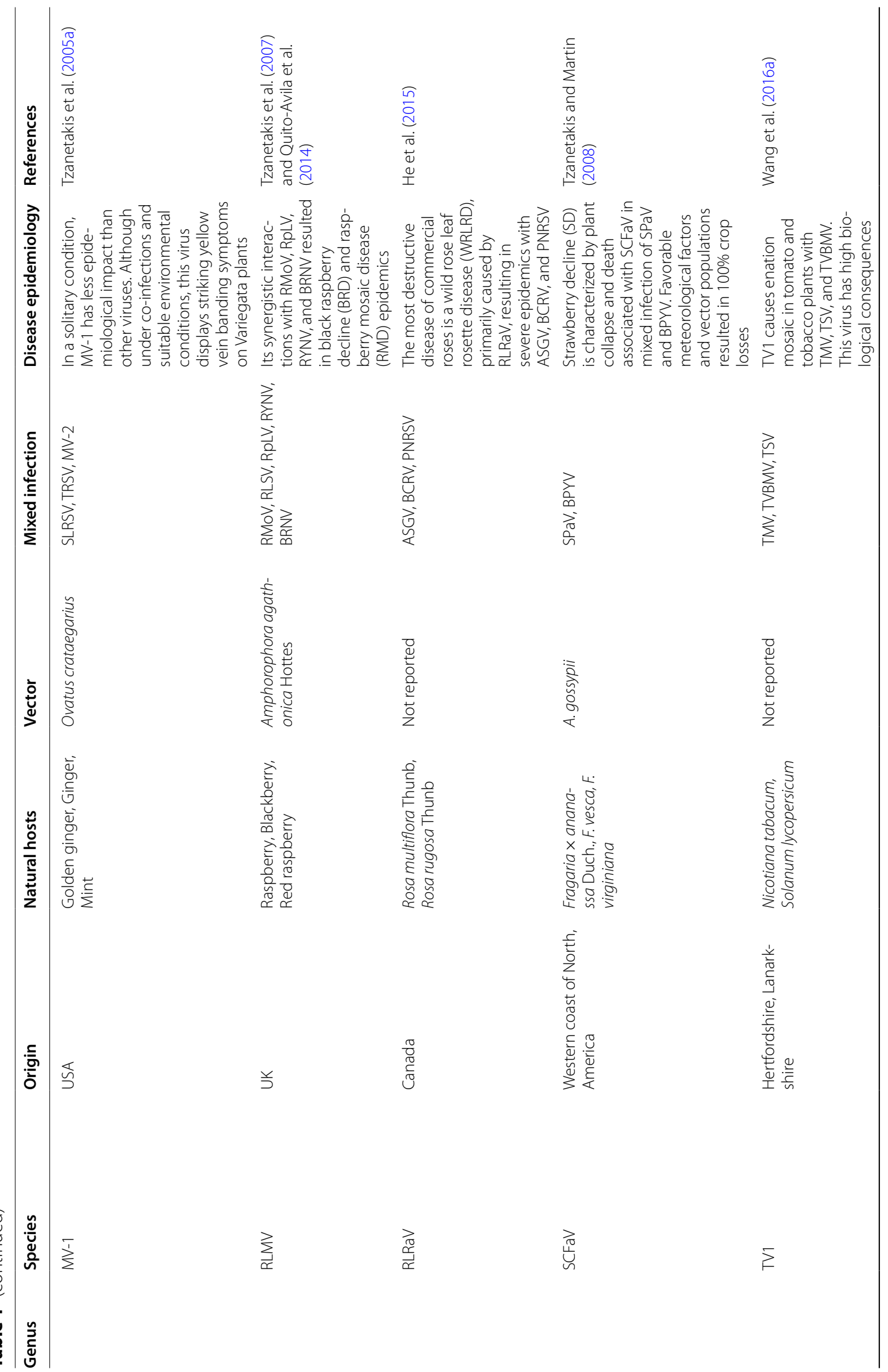


Fusain et al. Phytopathology Research $\quad$ (2021) 3:27

Page 11 of 36

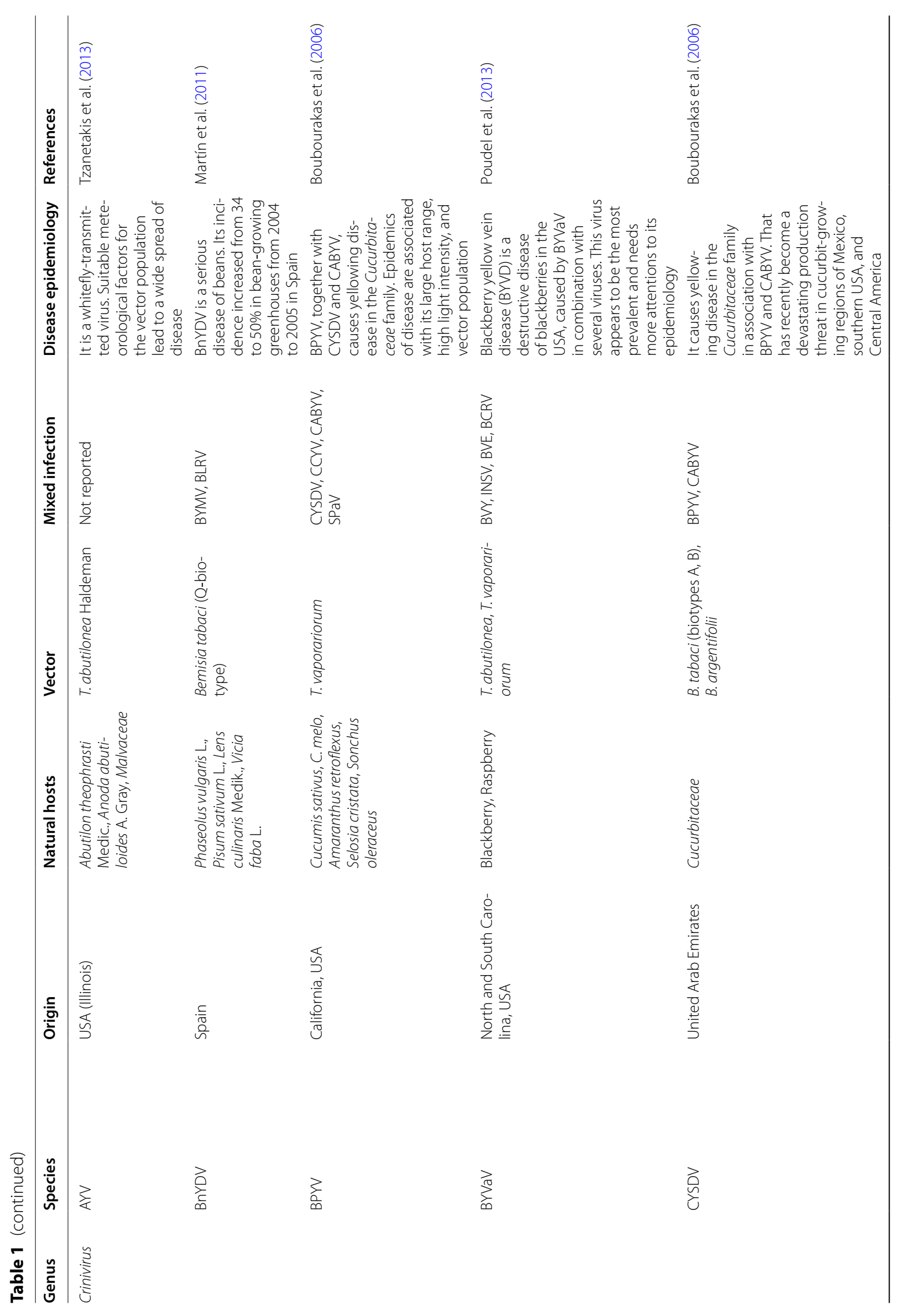




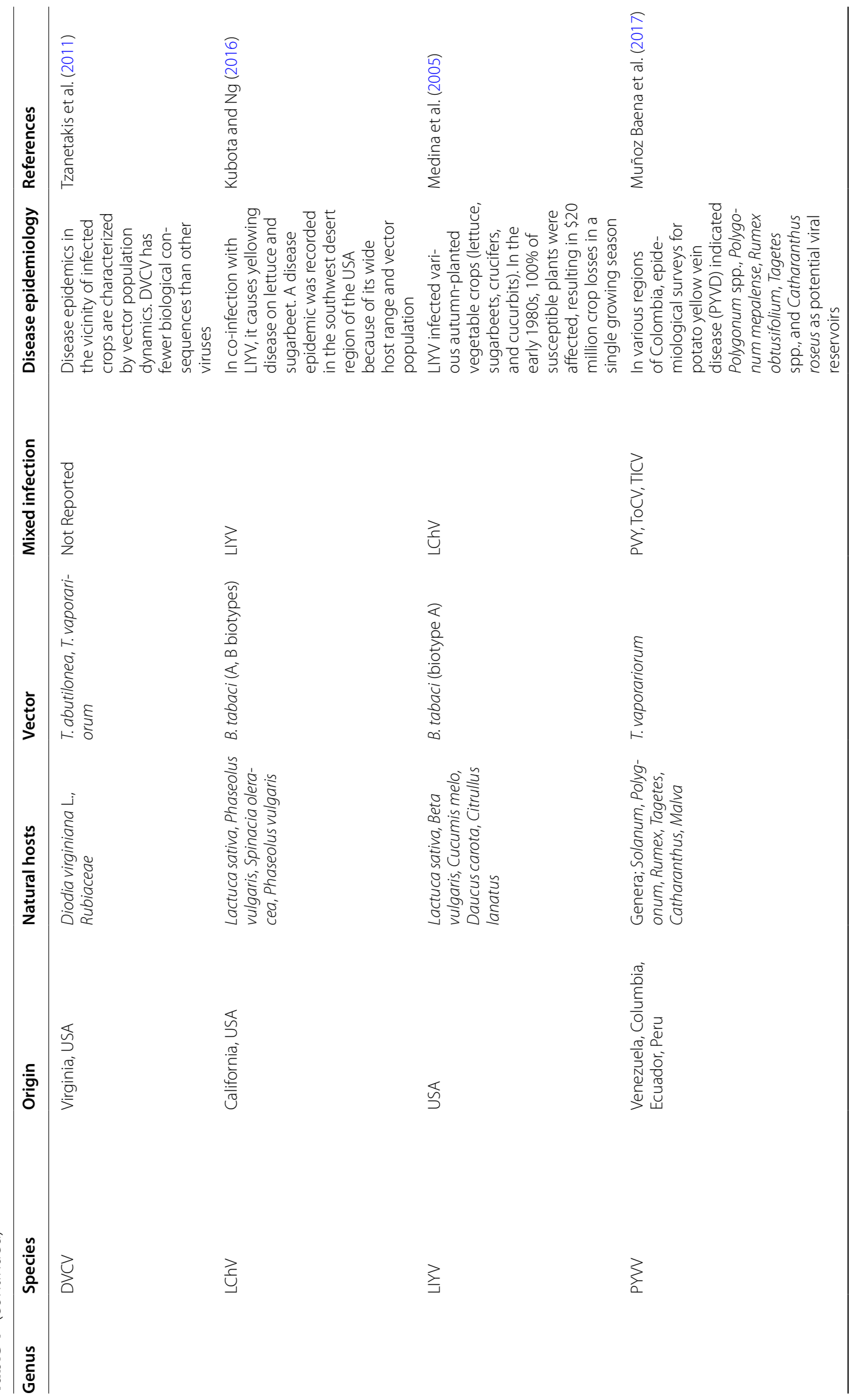


Fusain et al. Phytopathology Research $\quad$ (2021) 3:27

Page 13 of 36

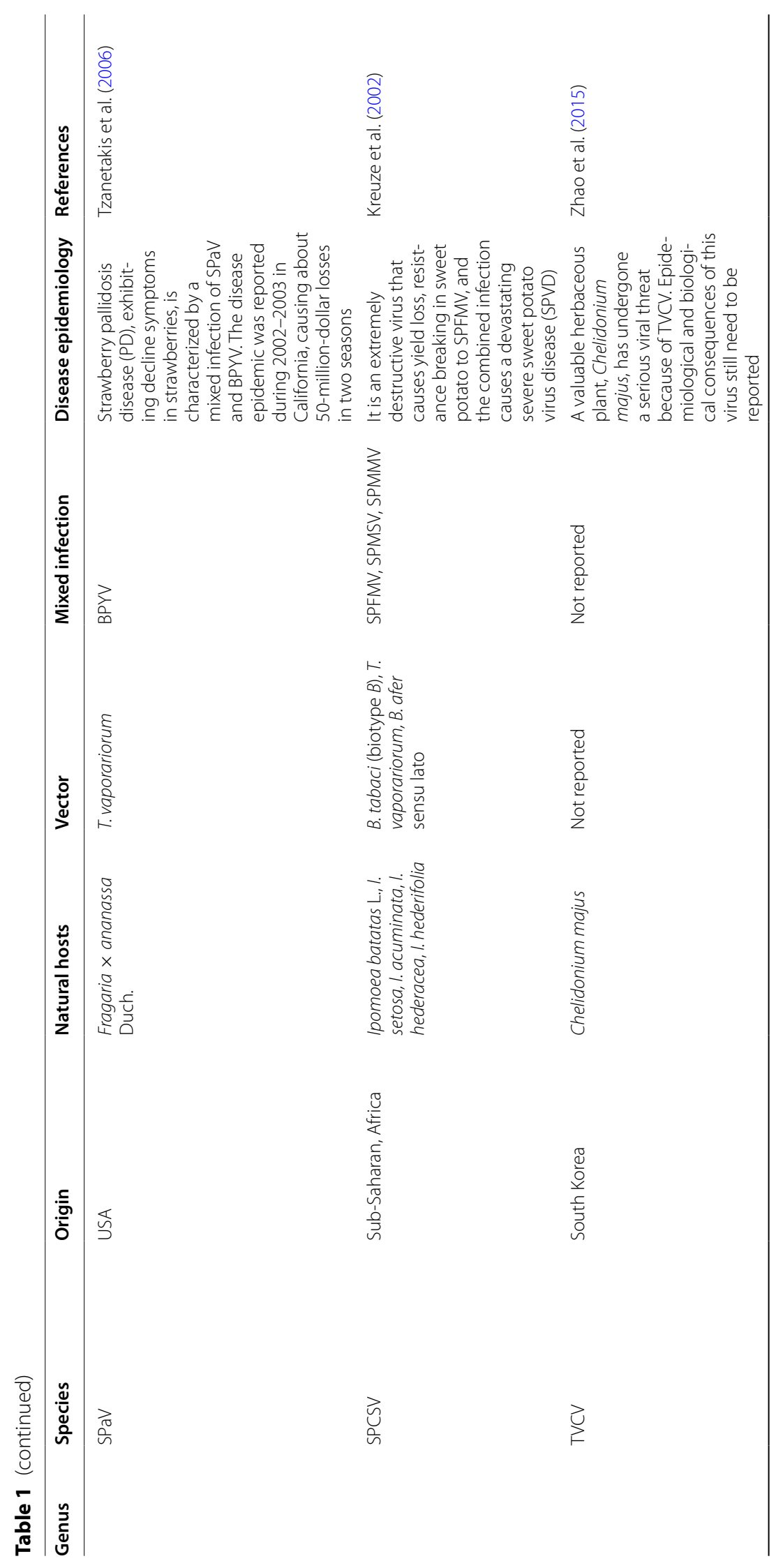



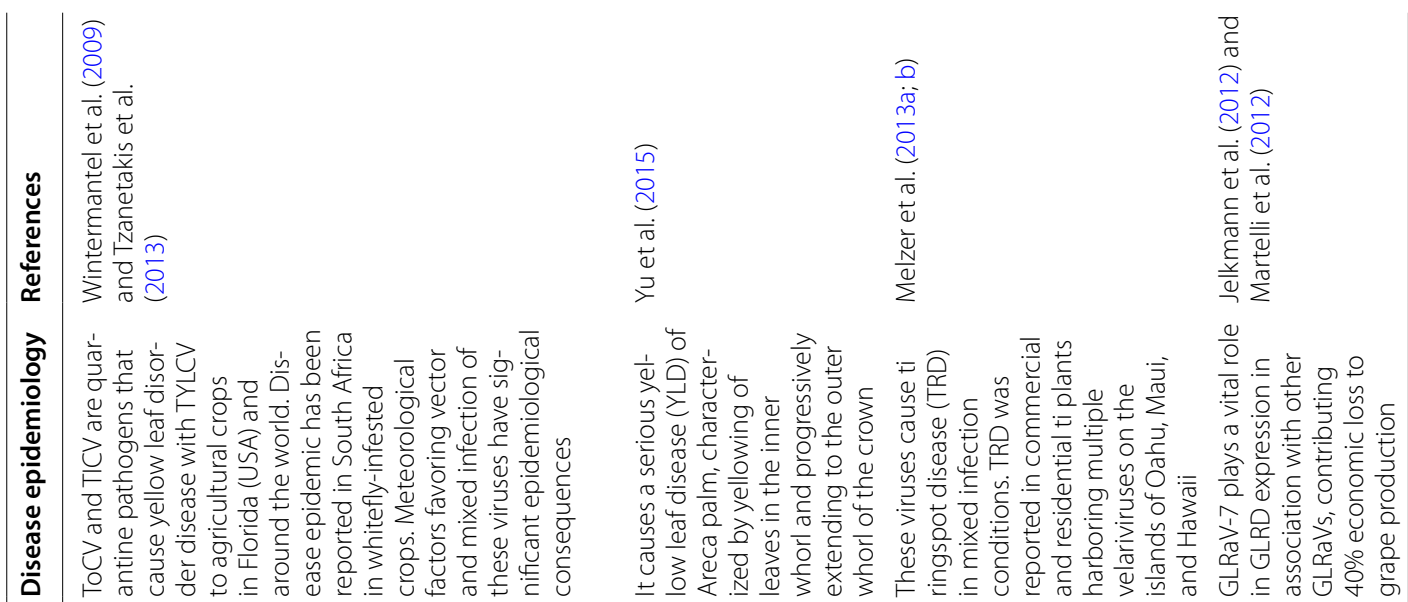

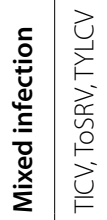
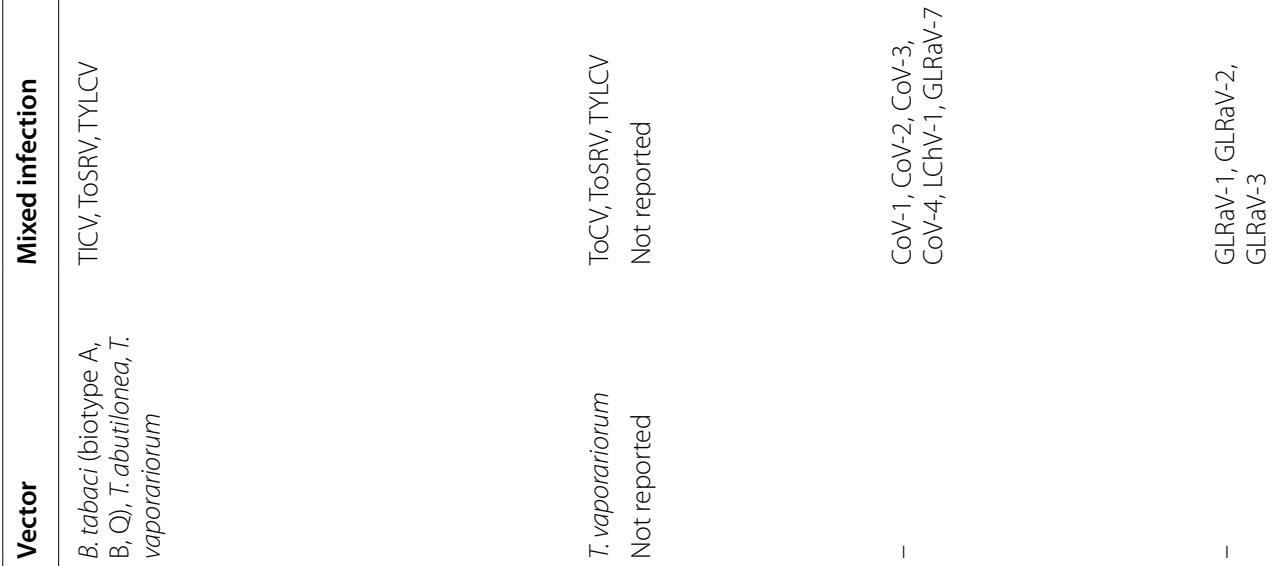
Fusain et al. Phytopathology Research $\quad$ (2021) 3:27

Page 15 of 36

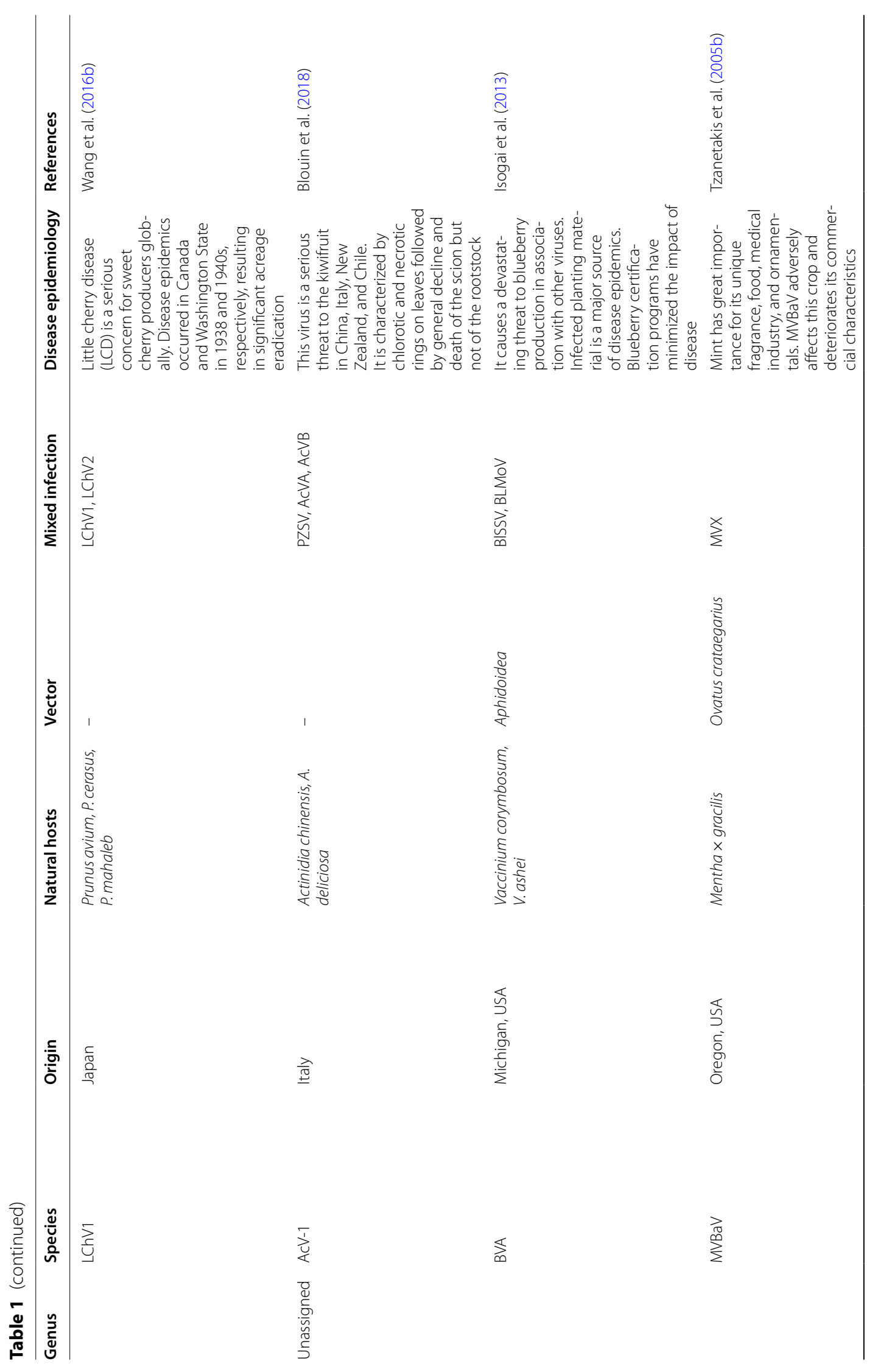




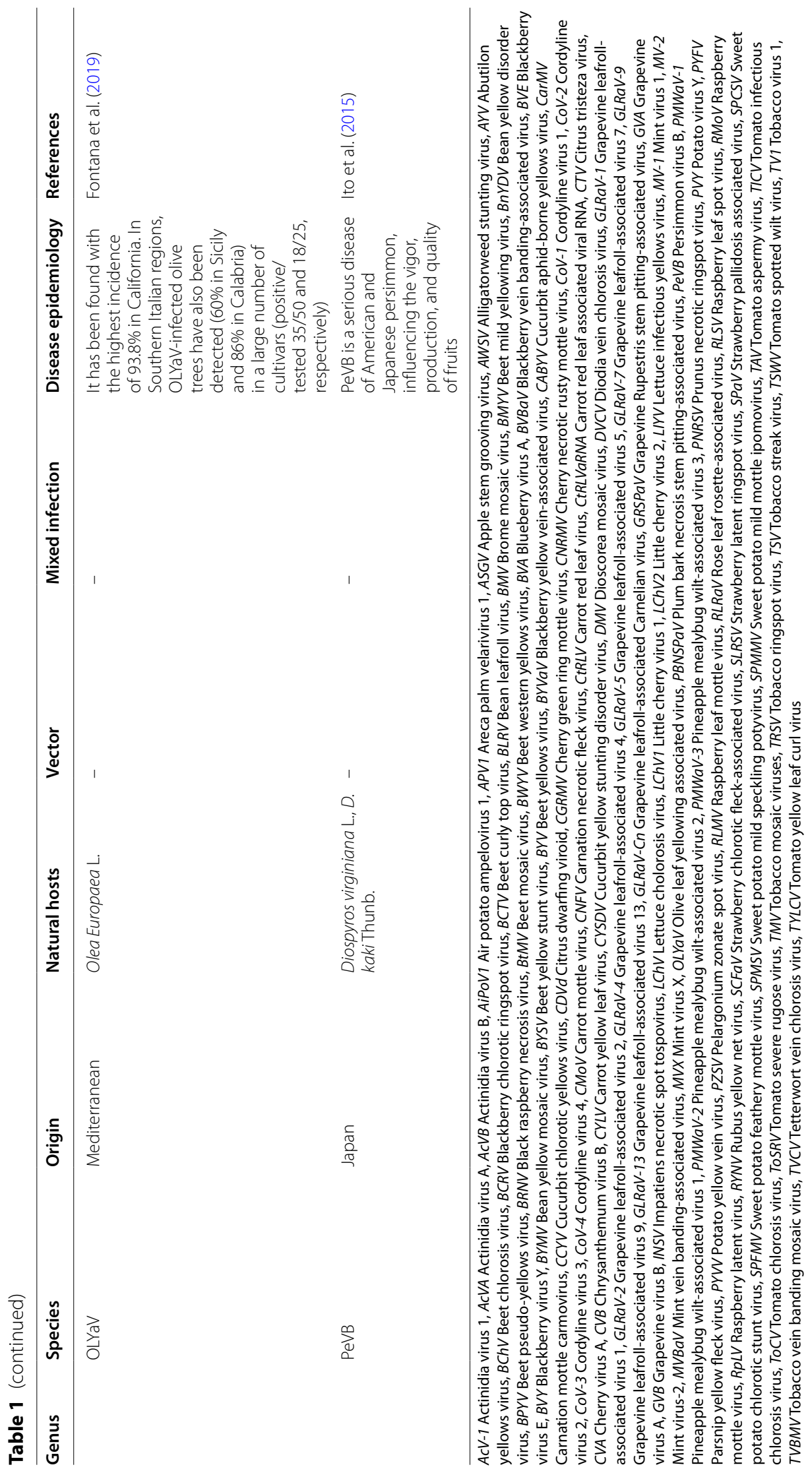




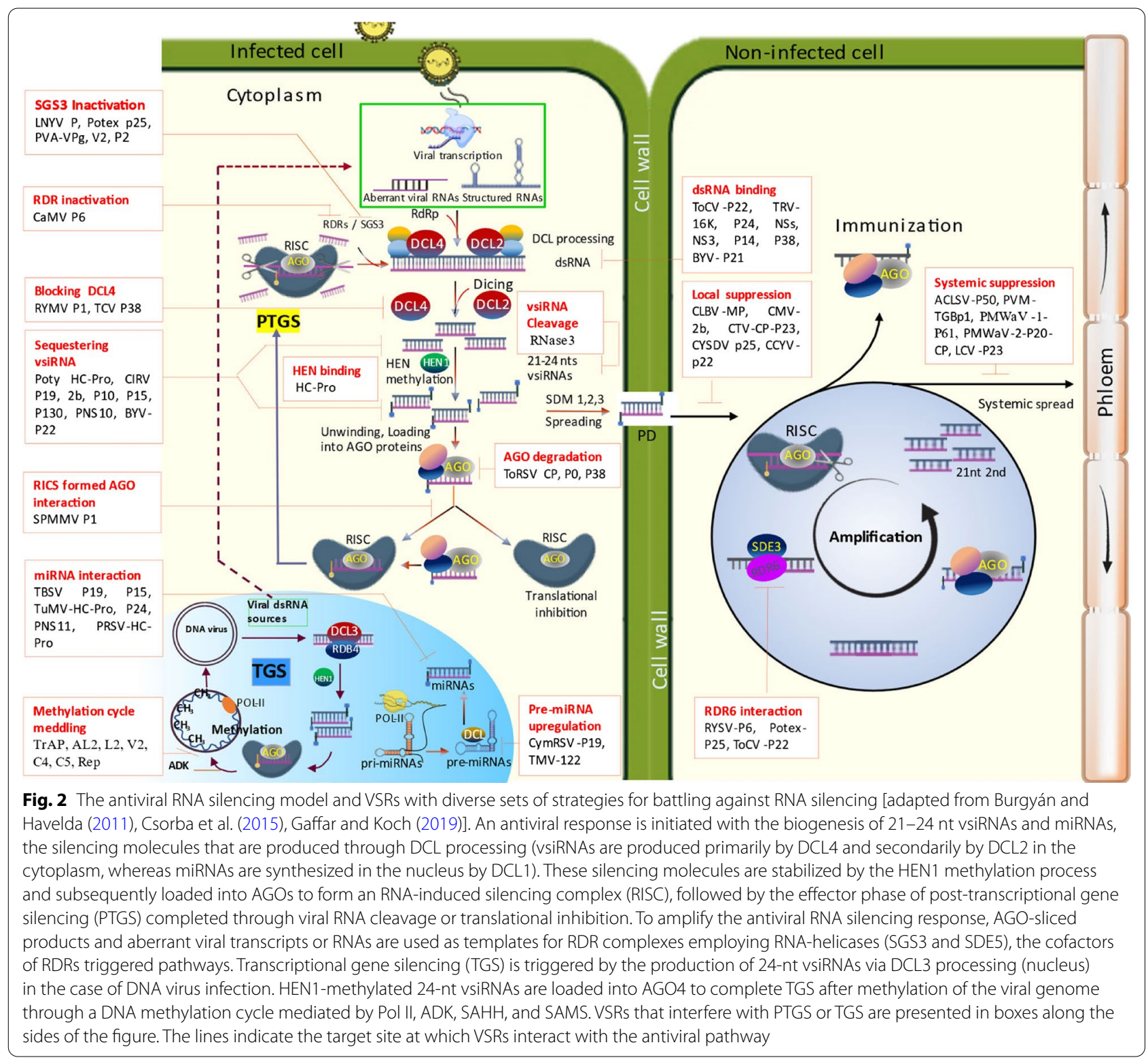

cells where local silencing signals have been received. These new dsRNAs are processed into secondary siRNAs through DCL4 and movement proceeds across additional 10-15 cells (Fig. 2). Therefore, the local and systemic silencing signaling events are mediated by primary and secondary vsiRNAs synthesis, respectively (Voinnet 2005; Melnyk et al. 2011; Mermigka et al. 2016).

\section{Viral strategies to evade antiviral RNA silencing}

PTGS is an important defense mechanism of plants against viral infection. To recruit a successful infection, viruses have evolved diversified strategies, of which the production of VSRs can negatively control PTGS by constraining miRNA and siRNA regulation in plants $(\mathrm{Hu}$ et al. 2020). Extensive studies on a large number of plant viruses have demonstrated the multi-functionality of VSRs. In addition to suppress RNA silencing, they also play significant roles as transcriptional activation factors (helicase, protease, and replicase), symptom determinants, as well as helper components in the viral infection process. Therefore, VSRs have evolved independently with no structural similarities, repressing antiviral RNA silencing in hosts by affecting the involved core components (Li and Wang 2019) (Table 2, Fig. 2). 


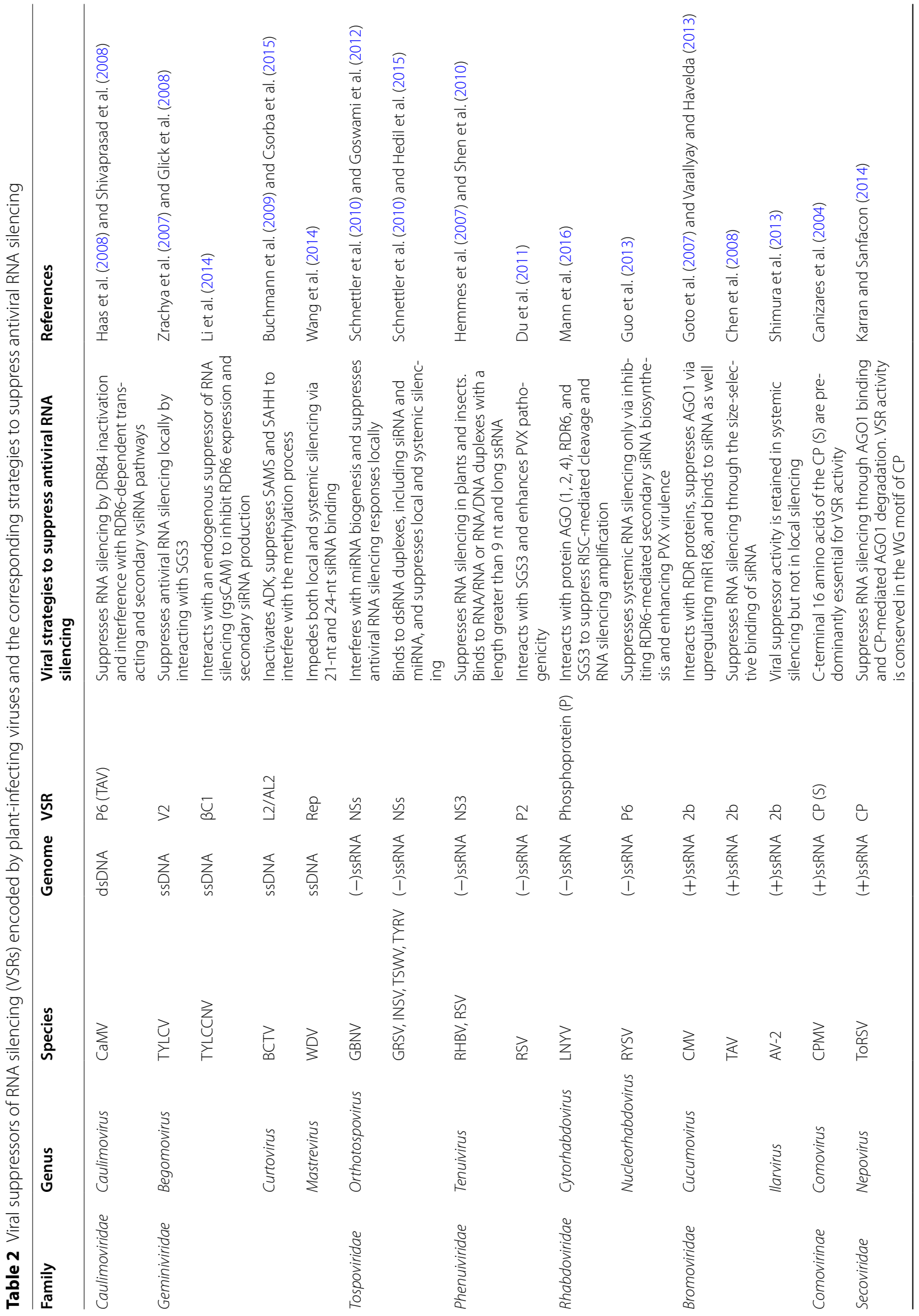




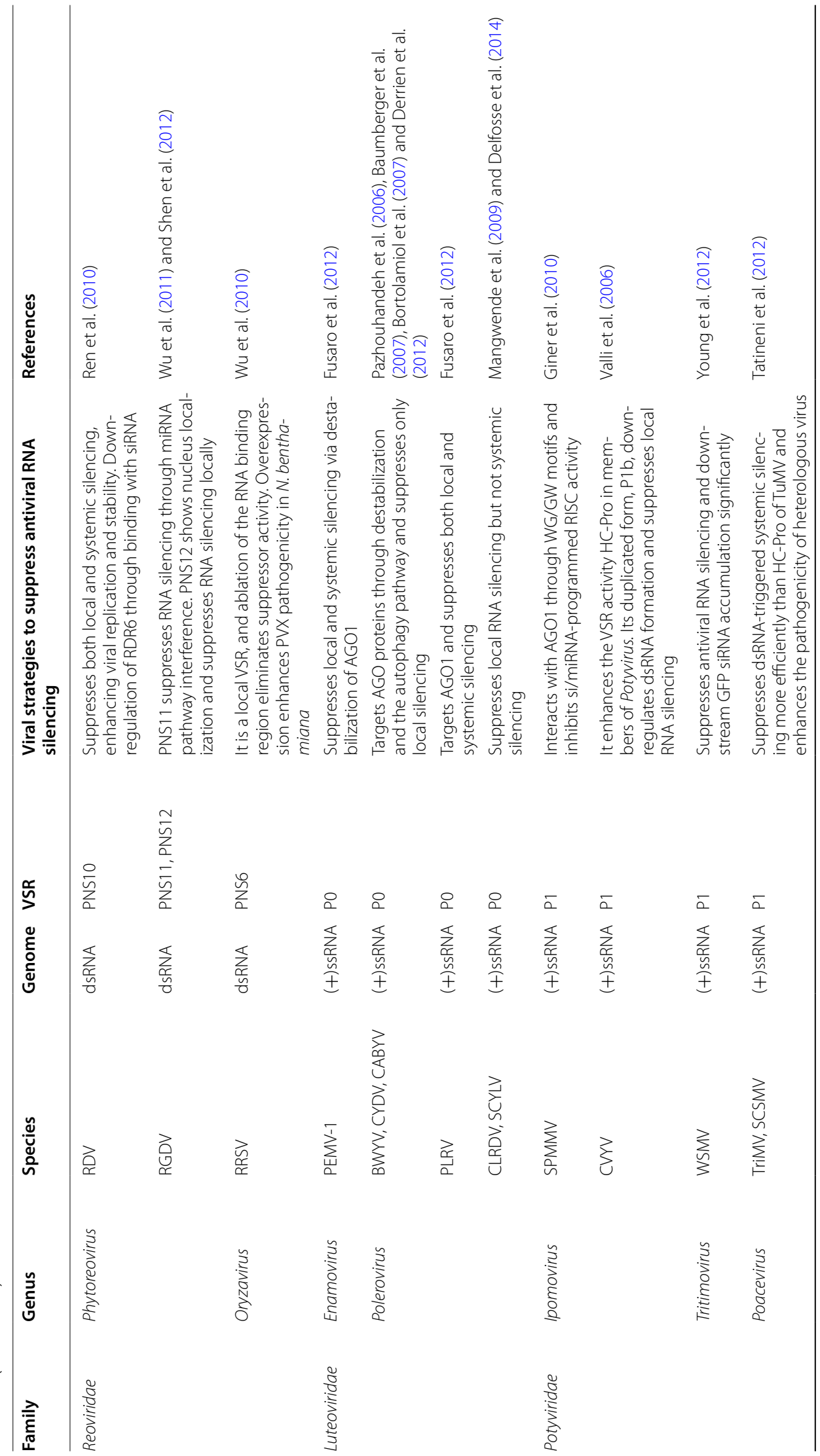




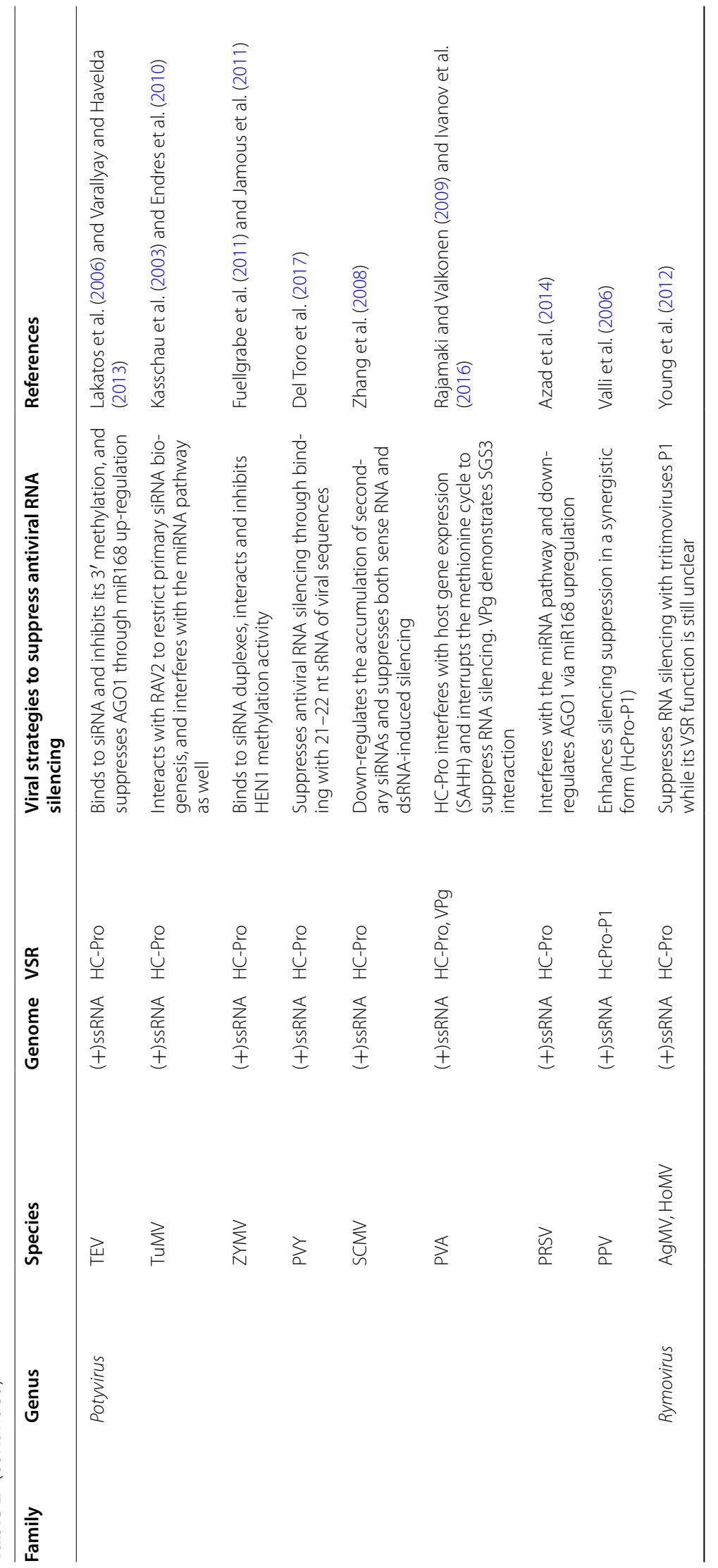




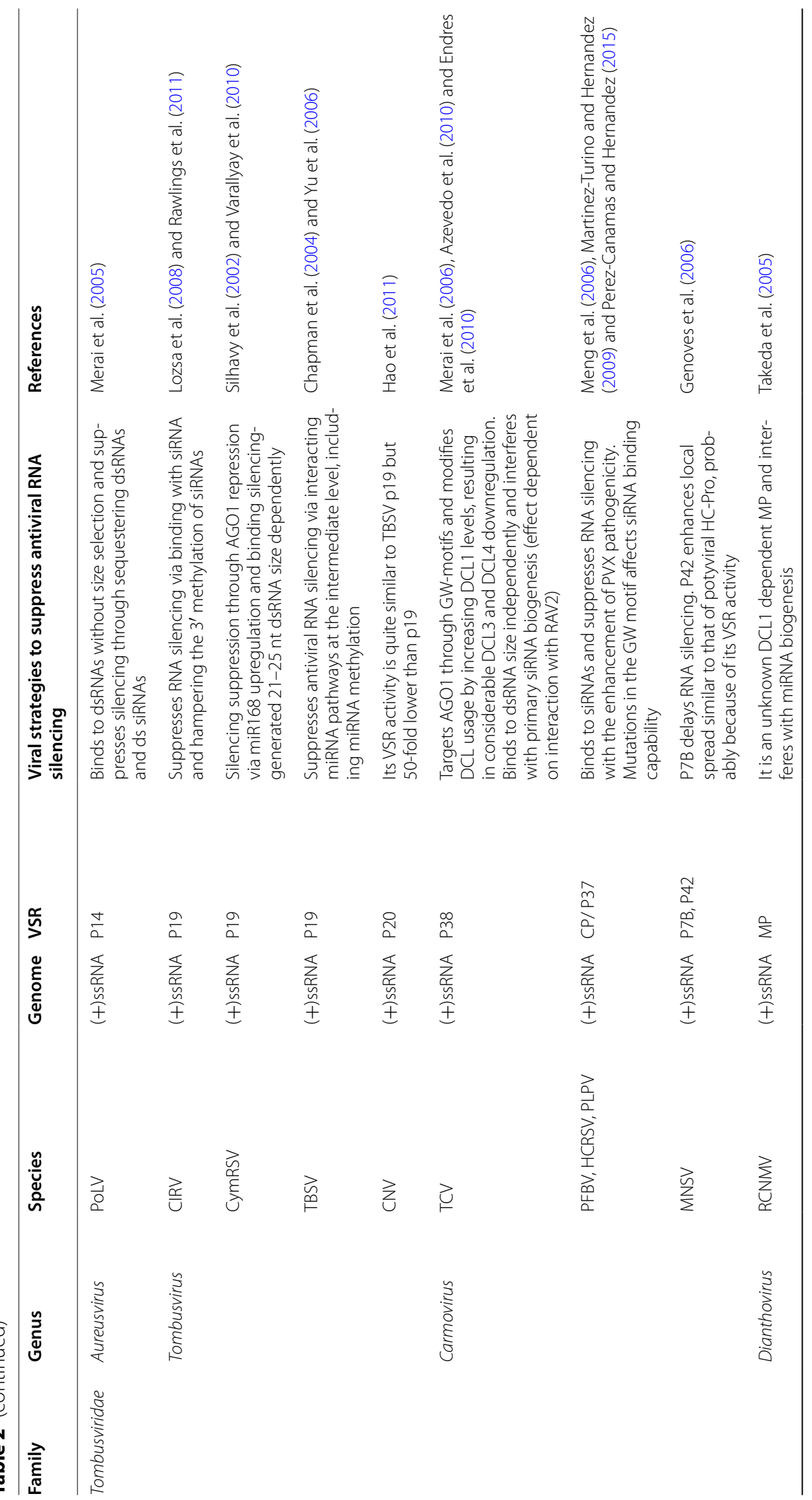




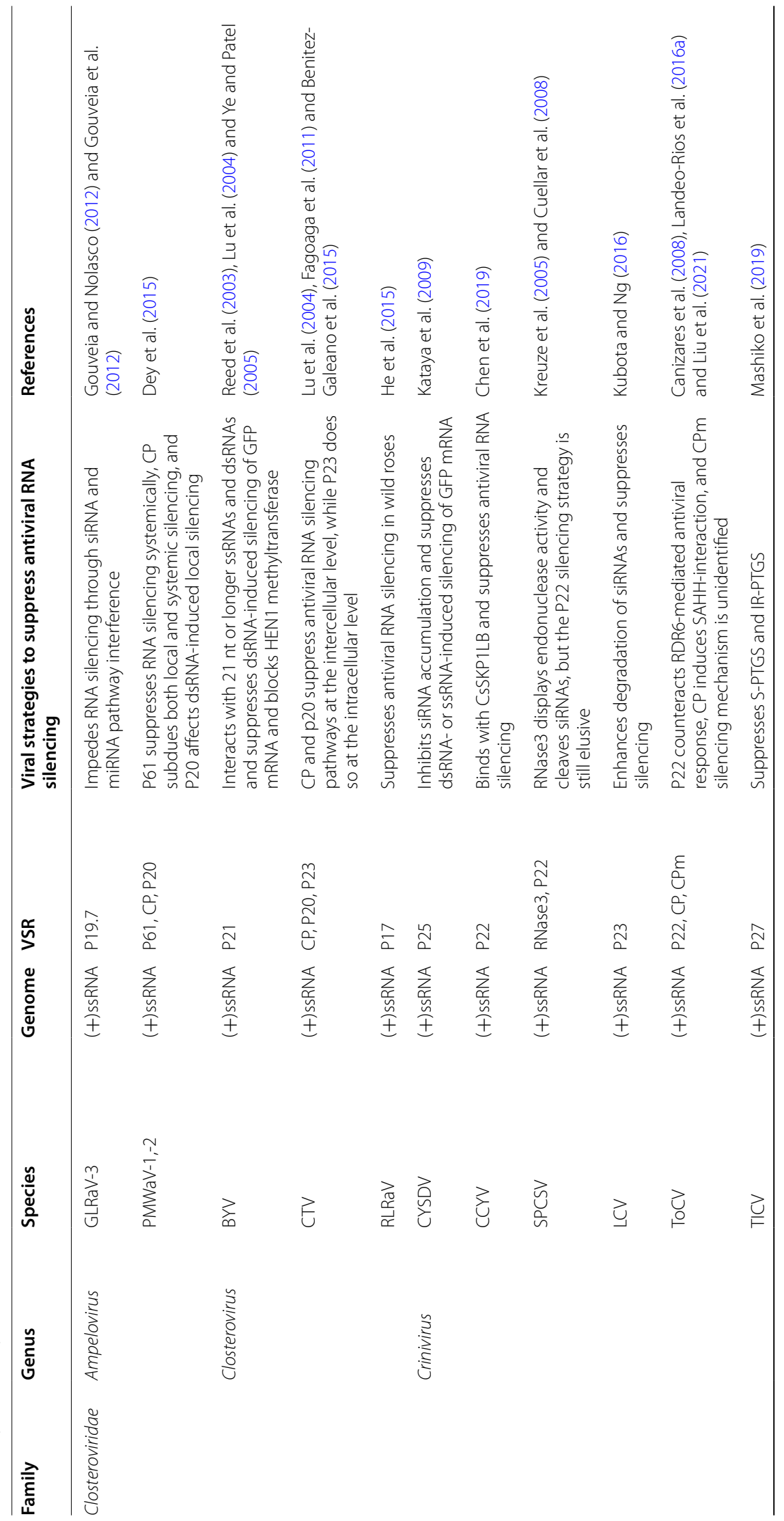




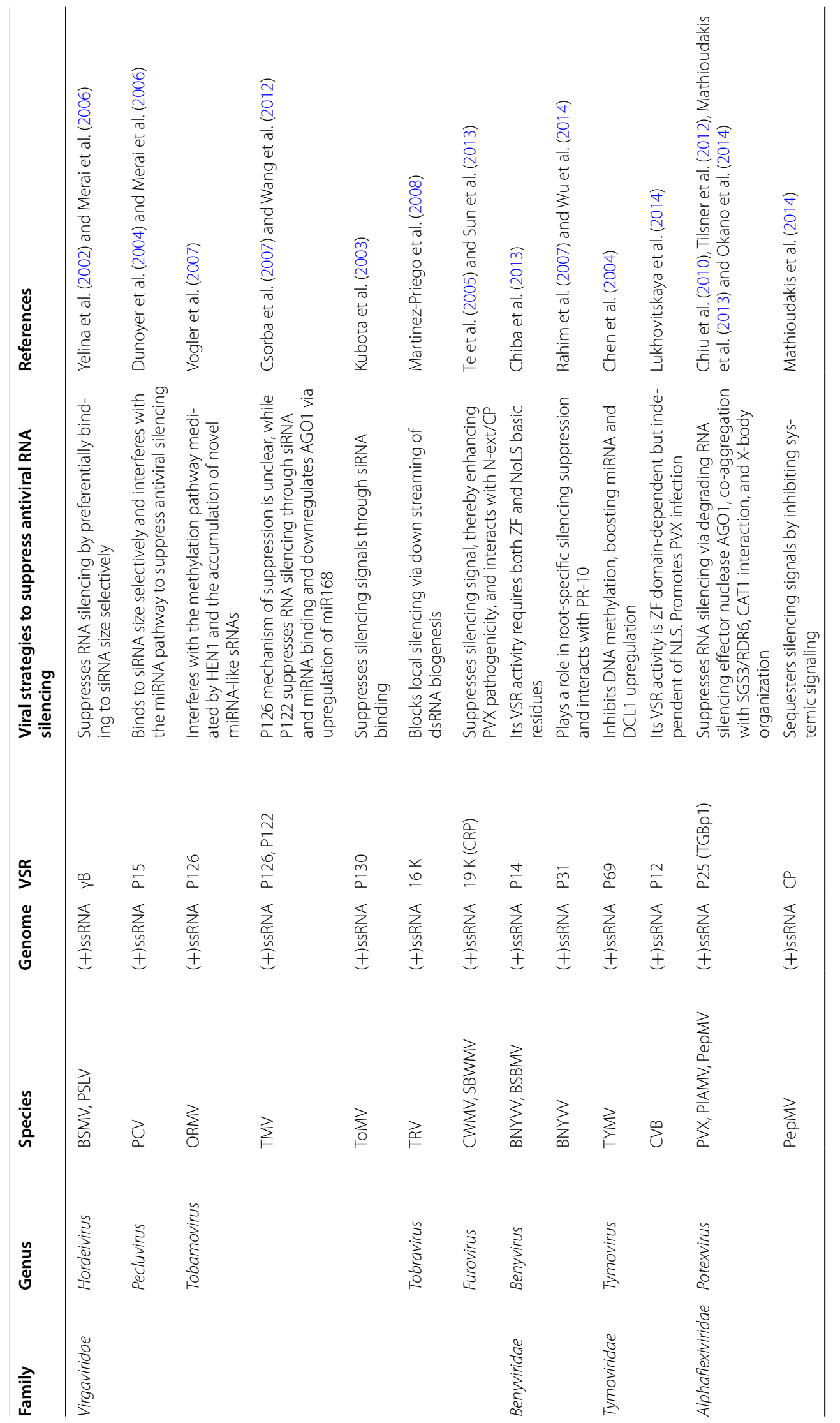




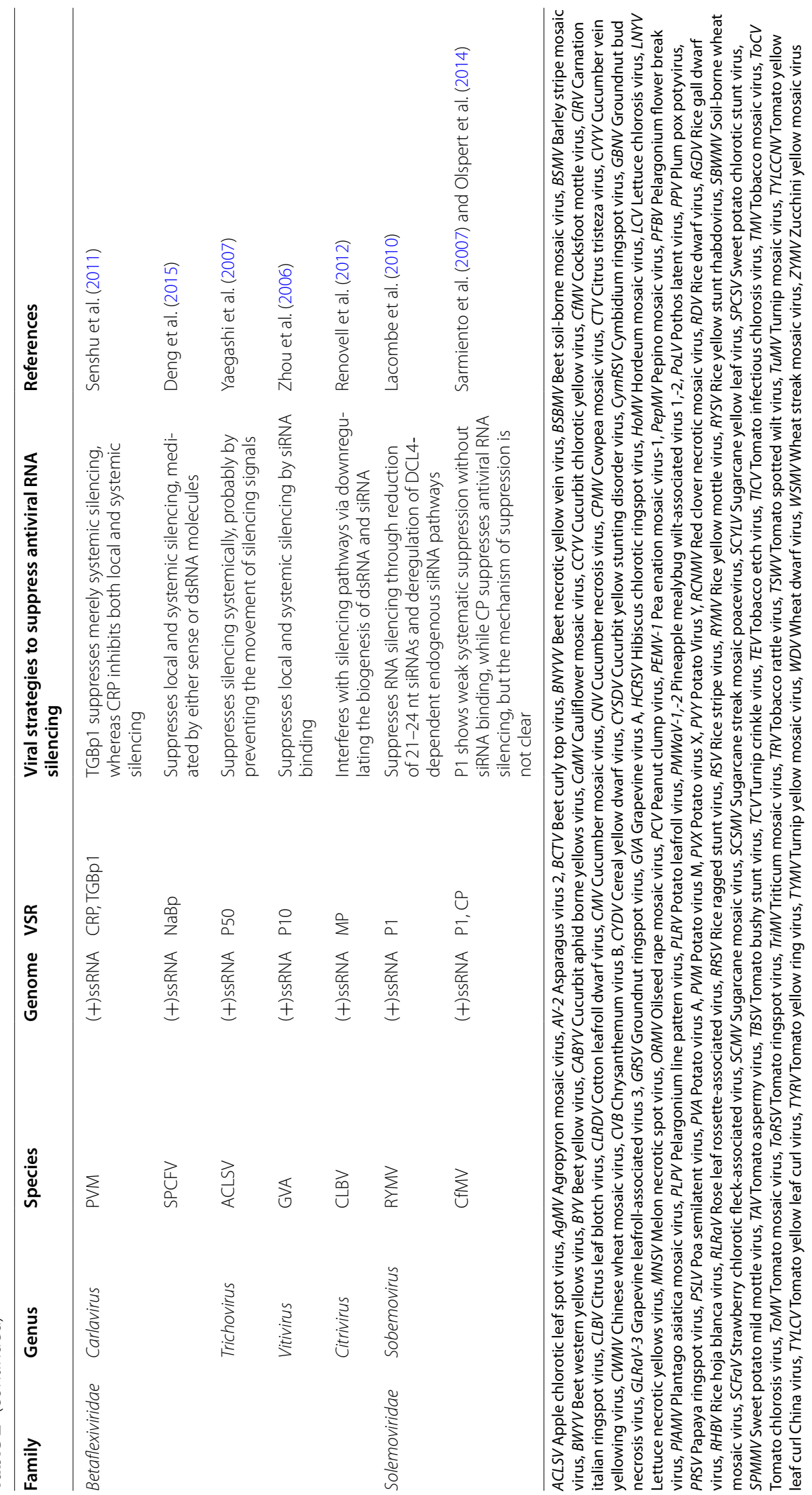




\section{Meddling with methylation cycle and suppressing TGS}

DNA viruses such as geminiviruses and their associated betasatellites encode VSRs to suppress TGS through inhibiting or degrading key regulators of the methylation cycle. For example, transcriptional activator protein (TrAP) of beet severe curly top virus (BSCTV), tomato golden mosaic virus (TGMV), and cabbage leaf curl virus $(\mathrm{CaLCuV})$, the pathogenicity factor $\beta \mathrm{C} 1$ of tomato yellow leaf curl China virus (TYLCCNV) and associated betasatellite, $\mathrm{C} 4$ protein of cotton leaf curl Multan virus (CLCuMuV), and L2 protein of beet curly top virus (BCTV), as well as AL2 protein of CaLCuV, can compromise the methylation process by impeding its major regulatory enzymes. These enzymes include $S$-adenosyl methionine synthetase (SAMS), adenosine kinase (ADK), and $S$-adenosyl homocysteine hydrolase (SAHH), which are also essential for TGS (Fig. 2) (Yang et al. 2011; Csorba et al. 2015; Jackel et al. 2015; Ismayil et al. 2018). Most geminiviruses, such as TGMV and CaLCuV, encode TrAP protein to activate the viral gene transcription by inhibiting the histone methyltransferase KYP/SUVH4 activity (Castillo-Gonzalez et al. 2015; Guerrero et al. 2020). Other geminiviral factors, including Rep, V2, C4, and C5, can also suppress TGS by interfering with methylation factors (Rodríguez-Negrete et al. 2013; Wang et al. 2018).

\section{Binding with dsRNA and cleaving vsiRNA}

The binding of VSRs to dsRNA is a general approach for VSRs to suppress RNA silencing. For example, various VSRs such as P38, P14, NS3, and NSs from turnip crinkle virus (TCV), pothos latent virus (PoLV), rice stripe virus (RSV)/rice hoja blanca virus (RHBV), and tomato spotted wilt virus (TSWV)/groundnut bud necrosis virus (GBNV), respectively, bind to dsRNA and inhibit the vsiRNA biogenesis (Fig. 2) (Yang and Li 2018). Strikingly, the sweet potato chlorotic stunt virus (SPCSV)-encoded VSR, RNase3, disables RNA silencing via an endonuclease activity-dependent pathway by cleaving dsRNA and vsiRNA duplexes (Cuellar et al. 2009).

\section{Interfering with RDR and DCL4}

The P6 suppressor protein of cauliflower mosaic virus (CaMV) binds with a double-stranded RNA-binding protein 4 (DRB4) to compromise the function of DCL4 in RNA-mediated PTGS. Moreover, P6 can also interfere with RDR6-dependent trans-acting and secondary vsiRNA pathways through interacting with DCL4 and impairing its functions (Haas et al. 2008; Shivaprasad et al. 2008). The TCV-associated P38 protein interacts with AGO1 and alters DCL usage by boosting DCL1 levels, resulting in significant downregulation of DCL3 and DCL4 (Azevedo et al. 2010; Endres et al. 2010).

\section{Binding with HEN and sequestrating vsiRNA}

As briefly described above, vsiRNA duplexes undergo methylation mediated by HEN1 before they are loaded onto AGOs. This methylation protects sRNAs from exonuclease degradation, facilitating systemic spread of antiviral RNA silencing signals. To counteract host antiviral RNA silencing, HC-Pro protein of zucchini yellow mosaic virus (ZYMV) binds to HEN1 and inhibits its methyltransferase activity (Jamous et al. 2011). Several VSRs, including $2 \mathrm{~b}$ protein of cucumber mosaic virus (CMV), p19 protein of tomato bushy stunt virus (TBSV), HC-Pro protein of turnip mosaic virus (TuMV), and p21 protein of beet yellow virus (BYV), can bind to miRNA and vsiRNA duplexes and prevent HEN1-mediated methylation (Burgyan and Havelda 2011; Duan et al. 2012). The sequestration of vsiRNA by VSRs has been demonstrated to inhibit the plant-mediated antiviral RNA silencing pathways.

\section{Degrading AGOs and interfering with RISC assembly}

The AGO family is characterized as a critical component of RISC assembly, and plays key regulatory functions during the process of antiviral RNA silencing. Several VSRs interact with AGO1 and suppress RNA silencing response (Müller et al. 2020), such as the Polerovirus F-box $\mathrm{P0}$, the tomato ringspot virus (ToRSV) $\mathrm{CP}$, and the TCV P38; they all target AGO1 and trigger its instability and degradation (Azevedo et al. 2010; Karran and Sanfacon 2014; Derrien et al. 2018). Interestingly, the $16 \mathrm{~K}$ protein of tobacco rattle virus (TRV) interacts with AGO4 and interferes with the assembly of RISC (Fernandez-Calvino et al. 2016). Similarly, the P1 protein of sweet potato mild mottle virus (SPMMV) suppresses RNA silencing by restricting RNA binding to AGO1, thus negatively regulates RISC assembly (Kenesi et al. 2017).

\section{Interacting with miRNA and upregulating pre-miRNA}

The miRNA is a discrete class of sRNA that triggers an antiviral defense against viral infection. However, several VSRs can interact with miRNA pathways to disrupt this antiviral function through upregulation of pre-miRNA. For instance, the rice gall dwarf virus (RGDV) PNS11 protein and the TBSV P19 protein suppress antiviral RNA silencing through interacting with miRNA pathways, including miRNA methylation ( $\mathrm{Yu}$ et al. 2006; Burgyan and Havelda 2011; Shen et al. 2012). Similarly, HC-Pro from papaya ringspot virus (PRSV) and tobacco etch virus (TEV), and P19 from cymbidium ringspot virus (CymRSV) repress AGO1 accumulation via upregulation of pre-miR168, leading to the suppression of antiviral RNA silencing (Varallyay et al. 2010; Varallyay and Havelda 2013; Azad et al. 2014). 
Meddling with the amplification of antiviral RNA silencing The amplification of RNA silencing is most important for the inhibition of viral infection. Therefore, plant recruits several RDR proteins and RNA-helicases (SGS3 and SDE5), the extremely crucial components in antiviral RNA silencing pathways, to perform this amplification. Plant viruses of different groups encode VSRs to interact with RDR6 and SGS3, resulting in the suppression of RDR-mediated pathways. Some VSRs, such as $\mathrm{VPg}$ and HC-Pro from potyviruses, $\beta \mathrm{C} 1, \mathrm{~V} 2$, and $\mathrm{AC} 2$ from geminiviruses, P2 from RSV, P6 from rice yellow stunt rhabdovirus (RYSV), and TGBp1 from plantago asiatica mosaic potexvirus (PlAMV), can bind to SGS3 and RDR6, and trigger the suppression of antiviral RNA silencing (Du et al. 2011; Guo et al. 2013; Cheng and Wang 2017) (Table 2, Fig. 2). Among them, V2 of CLCu$\mathrm{MuV}$ may also target calmodulin (CaM) to suppress anti-RNAi defense (Wang et al. 2021). In addition, V2 of TYLCV binds to SGS3 and suppresses RNA silencing locally (Glick et al. 2008). Whereas, $\beta C 1$ protein of TYLCCNV satellite suppresses RDR6 expression and secondary vsiRNA production by upregulating an endogenous suppressor of RNA silencing (rgsCAM) (Li et al. 2014). Moreover, both $2 \mathrm{~b}$ of CMV and p22 of tomato chlorosis virus (ToCV) interact with RDR6 to inhibit secondary vsiRNA biosynthesis (Landeo-Rios et al. 2016b).

\section{Inhibiting the spread of antiviral RNA silencing}

In virus-infected plants, local and systemic spread of silencing signal molecules constitutes the basis of antiviral RNA silencing pathways. To establish successful infection, viruses encode VSRs accordingly to target key regulators of these antiviral pathways. The Rep protein of wheat dwarf virus (WDV) suppresses RNA silencing locally and systemically through binding with vsiRNA duplexes (Wang et al. 2014). The P6 protein of RYSV suppresses systemic RNA silencing by constraining RDR6mediated biosynthesis of secondary vsiRNAs. Similarly, the CMV-encoded $2 \mathrm{~b}$ protein block the translocation of RNA silencing signals and inhibit their spread (Guo and Ding 2002). Moreover, the potato virus X (PVX) suppressor protein (p25) inhibits the production of RNA silencing signals and interferes with their propagation (Voinnet et al. 2016).

\section{Viral proteins of closterovirids to counteract antiviral RNA silencing GLRaV-2 $\mathrm{p} 24$ protein as a VSR}

The p24 protein of GLRaV-2 is a strong VSR encoded by a cryptic ORF in the viral genome. It can effectively block siRNA accumulation and suppress antiviral RNA silencing (Wang et al. 2019). The N-terminus (amino acids $1-188$ ) of $\mathrm{p} 24$ is a main functional region, comprising all predicted $\alpha$-helicases and $\beta$-strands that are most essential for its VSR activity. Moreover, self-interaction, pathogenicity, and silencing suppression of p24 are associated with its hydrophobic residues (135/F38/V85/V89/W149, V162/L169/L170). Specifically, p24 suppresses RNA silencing by adopting an RNA-binding strategy. Substituting two basic amino acid residues at positions 2 and 86 , which are involved in RNA-binding, totally negates the VSR activity of p24 (Liu et al. 2016). W54 in the WG/ GW-like motif (W54/G55) is also primarily significant for retaining p24 suppressor activity (Li et al. 2018). Furthermore, p24 has no physical interaction with AGO1 of $N$. benthamiana, and it up-regulates mRNA expression of AGO1 without boosting AGO1 degradation. This impact is specifically correlated with the VSR activity of p24, demonstrating that it may hamper miRNA-directed processes (Li et al. 2018).

\section{GLRaV-3 p19.7 protein as a VSR}

The $3^{\prime}$ end monopartite RNA genome of GLRaV-3 encodes a VSR (p19.7) with a molecular weight of around $20 \mathrm{kDa}$. The p19.7 protein demonstrates VSR activity in various silencing induction systems. This VSR shares several characteristics with p21, a BYV suppressor protein capable of overcoming powerful silencing inducers (Gouveia et al. 2012). In co-infiltration assays, the VSR activity of p19.7 varies among GLRaV-3 variants, resulting in variable levels of accumulation of green fluorescent protein (GFP) mRNA and specific siRNA in the transgenic $N$. benthamiana line 16c. A comparison analysis of protein sequences demonstrated that the substitutions of a few amino acids in p19.7 may be linked to the variation in its suppression activity (Gouveia and Nolasco 2012).

\section{PMWaV-1 p61 protein as a VSR}

The p61 protein is reported to have a systemic silencing suppressor activity up to 18 days post-infiltration (dpi) among the 3 -proximal ORFs of PMWaV-1 that encode p61, p24, CP, and Hsp70, while no protein with local suppressor activity was identified (Dey et al. 2015).

\section{PMWaV-2 p20 and CP proteins as VSRs}

It has been stated that the two $3^{\prime}$-proximal ORFs of PMWaV-2 encode CP and p20 proteins, which adversely affect the induction of secondary siRNAs and prevent the systemic spread of antiviral silencing signals. Therefore, $\mathrm{CP}$ and p20 proteins affect RNA silencing (both local and systemic) in $N$. benthamiana, while CPd and p22 proteins solely mitigate systemic silencing. In addition, p20 protein suppresses dsRNA-induced local silencing, 
specifically, when there are lower levels of dsRNA. Furthermore, it has also been indicated that p20 can boost the infectivity of PVX in $N$. benthamiana (Dey et al. 2015).

\section{BYV p21 protein as a VSR}

The $3^{\prime}$-proximal genomic region of BYV encodes a $21 \mathrm{kDa}$ protein ( $\mathrm{p} 21)$. The $\mathrm{p} 21$ protein belongs to an important gene family of alike proteins that are possessed by other viruses in the Closterovirus genus, exhibiting a silencing suppressor role. The p21 is capable of interfering and suppressing dsRNA-induced silencing of GFP mRNA, however, BYSV- and CTV-encoded VSRs, p22 and p20, only show weak suppressor activity as compared to BYV p21. BYV p21 exhibits its VSR functionality in two model systems. In the first system, dsRNA induces a robust silencing of reporter mRNA, while in the second system, weak silencing is initiated via ectopic expression of mRNA from a stronger promoter (Reed et al. 2003). Furthermore, the crystalline structure of p21 shapes an RNA binding octameric ring architecture with a large central cavity of $90 \AA$ diameter and the inner surface of the ring is positively charged. Tombusviruses VSRs, p19 and $\mathrm{p} 21$, both inhibit silencing through binding to siRNA directly. Contrastingly, besides interacting with peculiar dimeric-structured p19-siRNA duplex, BYV p21 is also a nucleic acid-binding protein that interacts in vitro with $21 \mathrm{nt}$ or longer ssRNAs and dsRNAs. This p21-adopted precise RNA binding structure highlights various open challenges to study the structure-based interaction mechanism of other VSRs (Ye and Patel 2005).

\section{CTV CP, p20, and $\mathrm{p} 23$ proteins as VSRs}

Three distinct VSRs such as CP, p20, and p23 are encoded by the 3'-proximal region of large RNA genome of CTV, protecting virus from the antiviral silencing machinery of its perennial woody citrus host (Hajeri et al. 2014). Unlike p20 and other VSRs known to interfere with intercellular silencing, such as CMV 2b and PVX p25, CP is a unique VSR that suppresses antiviral RNA silencing pathways at an intercellular level, and this is not associated with intracellular silencing suppression. CMV $2 \mathrm{~b}$ and $\mathrm{p} 20$ share features in silencing suppression, and are potent suppressors of intercellular silencing but incomplete in suppressing intracellular silencing, however, unlike CMV $2 \mathrm{~b}$, the intercellular silencing suppression of p20 is not linked to substantially declined DNA methylation of the target GUS transgene (Lu et al. 2004; Benitez-Galeano et al. 2015). In terms of local silencing suppressor activity, p23 is the most effective VSR among the three aforementioned CTV VSRs, and its localization is restricted to both the plasmodesmata and nucleus. Although p23 is a strong intracellular silencing suppressor like HC-Pro, it does not restrict intercellular silencing and DNA methylation of the target transgene. There are many conserved amino acids in p23 and mutations of E95A/V96A and M99A/L100AA may compromise its VSR activity and stability, furthermore, deletions of Q93A and R143A/ E144A completely abolish its VSR activity (Li et al. 2019). Moreover, ectopic expression of p23 enhances CTV accumulation and dispersion in woody hosts and, in addition, promotes systemic infection of the resistant sour orange host (Fagoaga et al. 2011).

\section{RLRaV $\mathrm{p} 17$ protein as a VSR}

RLRaV encodes a $17 \mathrm{kDa}$ protein (p17). Its BLASTp search results indicate conserved motif characteristics of the viral suppressor p20 superfamily, such as p23 or p20 of RLMV, CTV, and SCFaV. RLRaV uses p17 as a VSR to combat antiviral RNA silencing response in wild roses (Rosa multiflora Thumb) upon the occurrence of wild rose leaf rosette disease (He et al. 2015).

\section{CYSDV p25 protein as a VSR}

The papain-like protease proteins, including p25, p5.2, and p22, were hypothesized to have VSR activity. However, only p25 has been identified as a PTGS suppressor of CYSDV. Its VSR strategy is to suppress dsRNA- or ssRNA-induced silencing of GFP mRNA. In plant tissues where silencing is already established, it is unable to prevent silencing signals from spreading locally and restoring GFP expression. Therefore, p25 has no ostensible effects on the accumulation of siRNAs (Kataya et al. 2009).

\section{CCYV p22 protein as a VSR}

To combat antiviral RNA silencing, a putative suppressor protein $\mathrm{p} 22$ binds with CsSKP1LB, a Cucumis sativus ortholog of S-phase kinase-associated protein 1 (SKP1). It is reported that the F-box-like motif in this protein is most crucial for p22-mediated viral pathogenicity and VSR activity (Chen et al. 2019). CCYV p22 suppresses antiviral RNA silencing at a local level and does not affect local or systemic movement of RNA silencing signals. Moreover, it is comparatively weaker in suppressing local RNA silencing than ToCV p22 and CYSDV p25, the two well-known VSRs of criniviruses (Orfanidou et al. 2019).

\section{LCV p23 protein as a VSR}

LCV employs p23 as a sophisticated tool for evasion of host antiviral defense and modulation of disease symptoms. It has been demonstrated that p23 suppresses initiation of local silencing and enhances degradation as well as inhibits accumulation of siRNAs in infiltrated leaves. This protein may also inhibit cell-to-cell and long-distance movement of RNA silencing signals in 
GFP-transgenic $N$. benthamiana (line 16c). At an elevated incubation temperature, p23-agroinfiltrated $N$. benthamiana leaves exhibit localized necrosis and an increased disease severity (within $5 \mathrm{dpi}$ ). This is a novelty about the direct temperature effect on VSR, which has been given to p23 of LCV and has never before been reported in other viruses (Kubota and Ng 2016).

\section{SPCSV RNase3 and p22 as VSRs}

SPCSV genomic RNA demonstrates variability in gene contents at $3^{\prime}$ proximal ORFs. Therefore, molecular analysis shows heterogeneity at the p22- and RNase3-encoding regions of various SPCSV isolates. The Ugandan SPCSV isolate encodes p22 and RNase3 proteins, which are involved in RNA silencing suppression. RNase3 displays endonuclease activity and cleaves siRNA into $\sim 14$ nt products, enhancing VSR activity of p22. Furthermore, RNase3 expression alone in sweet potato plants is enough for breaking plant resistance to sweet potato feathery mottle virus (SPFMV) and developing this viral disease (Cuellar et al. 2008).

\section{ToCV p22, CP, and CPm as VSRs}

The bipartite genomic RNAs of ToCV encode multiple VSRs with diverse functions to compromise host antiviral defense. Upon heterologous expression, CP and CPm induce obvious systemic symptoms in $N$. benthamiana, including leaf curling, necrotic mottling, and leaf deformation within 5 dpi (Canizares et al. 2008). Meanwhile, p22 is a strong VSR that preferentially binds to long dsRNAs via a putative zinc finger motif, preventing them from being diced into siRNAs (Landeo-Rios et al. 2016b). By using a ToCV infectious clone based on ToCV-BJ isolate, a consistent expression of p22 was detected in $N$. benthamiana leaves (Zhao et al. 2013, 2016). Furthermore, p22 interferes with the auxin signaling pathway through binding to SKP1.1 via its C-terminus and disrupting SCF complex formation by competing with transport inhibitor response 1 (TIR1) to promote viral infection (Liu et al. 2021). RdRps play a significant role in antiviral defense, and the RDR6 of $N$. benthamiana is also involved in defense via combatting ToCV. In rdr6 mutant, p22 is dispensable for ToCV replication, while during systemic infection, p22 counteracts RDR6-mediated antiviral response (Landeo-Rios et al. 2016a). However, the heterologous expression of p22 causes an exacerbation of disease symptoms and ultimately the death of whole plants, although it could not complement suppressordefective mutant viruses (Landeo-Rios et al. 2017).

\section{TICV-p27 as a VSR}

The ORF2 of TICV-RNA1 encodes p27, with a genomic location similar to other criniviruses. It has been reported that p27 can suppress a sense transgene-induced PTGS (S-PTGS) and an inverted repeat-induced PTGS (IRPTGS) without inhibiting local and systemic movement of RNA silencing signals. Furthermore, upon heterologous expression, p27 induces more severe mosaic and necrosis symptoms with the accumulation of a heterologous virus (Mashiko et al. 2019).

\section{Plant strategies to counter viral suppression of RNA silencing}

Plants have evolved counter-suppression pathways to combat viral infection in response to VSR-mediated RNA silencing suppression. Primarily, upon recognizing invading viruses, the plant immune system upregulates the expression of resistance R genes (NBS-LRR), triggering host defensive components (i.e., $\mathrm{R}$ proteins, monitor or guard) to guard antiviral RNA silencing response (Shao et al. 2019). In addition to regulating immune system, plants may target VSRs directly to counter the RNA silencing suppression mechanism. For instance, the interaction of the TuMV suppressor protein VPg with SGS3 and RDR6 activates a versatile cellular mechanism in host plants, facilitating the degradation of the RDR6-SGS3-VPg complex through autophagy pathways and ubiquitination to boost host antiviral RNA silencing (Cheng and Wang 2017). Similarly, the calmodulin-like protein in tobacco (rgs-CaM) binds to VSRs, including $2 \mathrm{~b}$ of CMV and tomato aspermy virus (TAV) and HC-Pro of TuMV, to inhibit RNA silencing suppression through autophagy-mediated degradation of these VSRs (Nakahara et al. 2012). Plants may also trigger antiviral immune responses via regulating the components of RNA silencing pathway, such as dsRNAs. DsRNAs are conserved molecular patterns produced during virus replication and can induce PTI signaling pathway in plants. This dsRNA-mediated antiviral PTI, which requires patternrecognition co-receptor SERK1 rather than DCLs, elicits antiviral protection independent of RNA silencing. However, the underlying mechanism of the corresponding signaling pathway is still a matter of consideration (Niehl et al. 2016; Niehl and Heinlein 2019). Hence, plant antiviral RNA silencing, viral suppression of RNA silencing, and plant counter-suppression may result in an endless battle of survival between viruses and plants.

\section{Conclusions and future perspectives}

It is now evident that antiviral RNA silencing, together with its rudimentary role in antiviral defense, establishes a fundamental regulatory hub in plant immunity to counter large numbers of viral pathogens. However, antiviral RNA silencing pathways should evolve continuously and rapidly due to diverse silencing suppression strategies of VSR. Mostly, viral suppressors hinder RNA silencing 
pathways by targeting essential elements of siRNAs and miRNAs or proteins like DCLs and AGOs. The interconnections between VSRs and host factors have demonstrated that a single viral suppressor can target several elements in a silencing pathway. For example, potyvirus HC-Pro may interfere with the miRNA pathway via sequestering siRNA biogenesis, downregulating AGO1 expression, and preventing $3^{\prime}$ end methylation of siRNA (Azad et al. 2014; Pollari et al. 2020). Similarly, closterovirid p22 may also compromise the silencing pathway in several ways, including dsRNA binding, counteracting RDR6-mediated antiviral response, accelerating disease symptoms, and ultimately causing plant death upon heterologous expression (Landeo-Rios et al. 2016b) (Fig. 2). Even though investigations into the mechanism of VSR have been on the frontline for more than a decade, many aspects are still indefinable. Interestingly, several VSRs, such as CP, movement protein, protease, and replicase, have analogous functions. Therefore, silencing activities and non-silencing functions should be coordinated to accomplish various tasks and attain optimal infection.

The structure-based interaction mechanism of VSRs is still elusive, although the precise adopted RNA binding octameric ring structure of closterovirid p21 and specific dimeric structured p19-siRNA duplex interaction have revealed various open challenges to investigate structure-based interaction mechanisms of other VSRs (Ye and Patel 2005). In addition, VSRs are supposed to be major contributors to viral disease induction and symptom development due to their negative effects on endogenous small RNA accumulations (Diaz-Pendon et al. 2007). Regardless of the paramount importance of VSRs in counteracting PTGS, their symptom induction is a less-studied aspect of the virus infection process. Furthermore, the direct temperature impact on VSR in modulation of disease symptoms needs more investigations. So far, only p 23 of LCV was reported to evade host antiviral defense at elevated temperature (Kubota and $\mathrm{Ng}$ 2016).

The molecular characteristics of VSRs are much more complex than we thought. Indeed, the p38 protein of $\mathrm{TCV}$, in addition to dsRNA binding, specifically interferes with the biogenesis of primary vsiRNA through downregulation of DCL4 (Azevedo et al. 2010). Similarly, the p19 protein of CymRSV confiscates vsiRNA through binding with 21-25 nt dsRNA and upregulating miR168 expression, resulting in arrests of antiviral AGO1 translation (Silhavy et al. 2002; Varallyay et al. 2010). Some other VSRs may interact with RNA silencing pathways in multiple ways, which need further investigations.

There are still a lot of lapses in knowledge about plant effectors regarding their silencing mechanisms and $\mathrm{mi} /$ siRNA RISC assemblies or some components of plant
RISCs, which are potential targets of VSRs. Therefore, VSRs like p38, P1, and P0 may be used as a powerful tool to explore the RISC complexes in future research.

Plant resistant (R) proteins have evolved to recognize strategies of VSRs against RNA silencing. Therefore, the identity of such dedicated proteins, specifically in guarding the RNA silencing components among the plethora of plant $\mathrm{R}$ proteins, is an important future question. Presumably, hosts can also neutralize VSRs through appropriate defensive activities that degrade or displace them into inappropriate subcellular compartments. The former probably has explained that the alleles of CMV-encoded VSR $2 b$ protein fail to accumulate in Arabidopsis because of proteolysis, while nuclear re-localization of tombusviral p19 is caused by its interaction with plant ALY protein (Canto et al. 2006; Zhang et al. 2006). These observations of hostdirected suppression mechanisms of VSRs and their polymorphic alleles may propose a future direction to study the variations in viral vulnerability between species or subspecies.

\section{Abbreviations}

ADK: Adenosine kinase; AGO: Argonaute; BCTV: Beet curly top virus; BMV: Brome mosaic virus; BSCTV: Beet severe curly top virus; BYSV: Beet yellow stunt virus; BYV: Beet yellow virus; CaLCuV: Cabbage leaf curl virus; CaM: Calmodulin; CaMV: Cauliflower mosaic virus; CCYV: Cucurbit chlorotic yellow virus; $\mathrm{CLCU}$ MuV: Cotton leaf curl multan virus; CMV: Cucumber mosaic virus; CTV: Citrus tristeza virus; CymRSV: Cymbidium ringspot virus; CYSDV: Cucurbit yellow stunting disorder virus; DCL: Dicer like; DRB4: Double-RNA binding protein 4; ER: Endoplasmic reticulum; ETI: Effector-triggered immunity; GBNV: Groundnut bud necrosis virus; GLRaV-3: Grapevine leafroll-associated virus 3; HC-Pro: Helper component-proteinase; HEN1: HUA enhancer 1; HSP7Oh: Heat-shock proteins HSP70 homology; HR: Hypersensitive responses; ICTV: International Committee on Taxonomy of Viruses; IR-PTGS: Inverted repeat-induced PTGS; LCV: Lettuce chlorosis virus; miRNAs: MicroRNAs; MVBaV: Mint vein banding-associated virus; PAMPs: Pathogen-associated molecular patterns; PIAMV: Plantago asiatica mosaic potexvirus; PMWaV-1: Pineapple mealybug wilt-associated virus 1; PMWaV-2: Pineapple mealybug wilt-associated virus-2; Pol II: Polymerase II; PoLV: Pothos latent virus; pri-miRNAs: Primary miRNAs; PRSV: Papaya ringspot virus; PTGS: Post-transcriptional gene silencing; PTI: PAMP-triggered immunity; PVX: Potato virus X; RdRp: RNA-dependent RNA polymerase; RDR: Cellular RdRps; RGDV: Rice gall dwarf virus; RHBV: Rice hoja blanca virus; RISC: RNA-induced silencing complex; RLMV: Raspberry leaf mottle virus; RLRaV: Rose leaf rossette-associated virus; RSV: Rice strip virus; RYSV: Rice yellow stunt rhabdovirus; SAHH: S-adenosyl homocysteine hydrolase; SAMS: S-adenosyl methionine synthetase; SAR: Systemic acquired resistance; siRNAs: Small interfering RNAs; SKP1: S-phase kinase associated protein 1; SMD: Silencing movement deficient; SPCSV: Sweet potato chlorotic stunt virus; SPFMV: Sweet potato feathery mottle virus; SPMMV: Sweet potato mild mottle virus; S-PTGS: Sense-transgene-induced PTGS; TBSV: Tomato bushy stunt virus; TCV: Turnip crinkle virus; TEV: Tobacco etch virus; TGMV: Tomato golden mosaic virus; TGS: Transcriptional gene silencing; TICV: Tomato infectious chlorosis virus; TIR1: Transport inhibitor response 1; ToCV: Tomato chlorosis virus; ToRSV: Tomato ringspot virus; TrAP: Transcriptional activator protein; TRV: Tobacco rattle virus; TSWV:Tomato spotted wilt virus; TUMV:Turnip mosaic virus; TYLCCNV: Tomato yellow leaf curl China virus; UPS: Ubiquitin proteasome system; VAMP: Virus-associated molecular pattern; vsiRNAs: Virus-derived small interfering RNAs; VSR: Viral suppressor of RNA silencing; WDV: Wheat dwarf virus; ZYMV: Zucchini yellow mosaic virus. 


\section{Acknowledgements}

We would like to express our gratitude and appreciation to Prof. Zaifeng Fan for his valuable suggestions on this manuscript. Please accept our heartfelt apologies to colleagues whose work could not be discussed due to space limitations.

\section{Authors' contributions}

$\mathrm{MDH}$ and $\mathrm{TZ}$ conceived the idea and wrote the manuscript. MDH, TF and XC designed and made the Figures and Tables. MT, TJ, TF, SL, and TZ edited and revised the manuscript. All authors read and approved the final manuscript.

\section{Funding}

This work was supported by Beijing Innovation Consortium of Agriculture Research System (Grant Number: BAIC01-2018-2021), the Chinese Universities Scientific Fund (2019TC064), and China Scholarship Council (Award Number: 2017GXZ004561).

\section{Availability of data and materials}

Not applicable.

\section{Declarations}

Ethics approval and consent to participate

Not applicable.

\section{Consent for publication}

Not applicable.

\section{Competing interests}

The authors declare that they have no competing interests.

\section{Author details}

'State Key Laboratory for Agro-Biotechnology, and Ministry of Agriculture and Rural Affairs, Key Laboratory for Pest Monitoring and Green Management, Department of Plant Pathology, China Agricultural University, Beijing 100193, China. ${ }^{2}$ Plant Protection Research Institute and Guangdong Provincial Key Laboratory of High Technology for Plant Protection, Guangdong Academy of Agricultural Sciences, Guangzhou 510640, China. ${ }^{3}$ Department of Plant Pathology, and Ministry of Agriculture and Rural Affairs Key Laboratory of Pest Monitoring and Green Management, and Ministry of Education Joint Laboratory for International Cooperation in Crop Molecular Breeding, China Agricultural University, Beijing 100193, China.

Received: 7 July 2021 Accepted: 4 November 2021

Published online: 15 November 2021

\section{References}

Adams IP, Skelton A, Macarthur R, Hodges T, Hinds H, Flint L, et al. Carrot yellow leaf virus is associated with carrot internal necrosis. PLoS ONE. 2014;9:e109125. https://doi.org/10.1371/journal.pone.0109125.

Agranovsky AA. Closteroviruses: molecular biology, evolution and interactions with cells. In: Gaur R, Petrov N, Patil B, Stoyanova M, editors. Plant viruses: evolution and management. Singapore: Springer; 2016. p. 231-52. https://doi.org/10.1007/978-981-10-1406-2_14.

Azad MAK, Amin L, Sidik NM. Gene technology for papaya ringspot virus disease management. Sci World J. 2014;2014:768038. https://doi.org/ 10.1155/2014/768038.

Azevedo J, Garcia D, Pontier D, Ohnesorge S, Yu A, Garcia S, et al. Argonaute quenching and global changes in Dicer homeostasis caused by a pathogen-encoded GW repeat protein. Genes Dev. 2010;24:904-15. https://doi.org/10.1101/gad.1908710.

Balint-Kurti P. The plant hypersensitive response: concepts, control and consequences. Mol Plant Pathol. 2019;20(8):1163-78. https://doi.org/10.1111/ mpp. 12821

Baltusnikas J, Satkauskas S, Lundstrom K. Long-term transcriptional gene silencing by RNA viruses. Trends Biochem Sci. 2018;43(6):397-401. https://doi.org/10.1016/j.tibs.2018.03.003.
Baumberger N, Tsai CH, Lie M, Havecker E, Baulcombe DC. The polerovirus silencing suppressor P0 targets ARGONAUTE proteins for degradation. Curr Biol. 2007;17(18):1609-14. https://doi.org/10.1016/j.cub.2007.08. 039.

Benitez-Galeano MJ, Rubio L, Bertalmio A, Maeso D, Rivas F, Colina R. Phylogenetic studies of the three RNA silencing suppressor genes of south American CTV isolates reveal the circulation of a novel genetic lineage. Viruses. 2015;7(7):4152-68. https://doi.org/10.3390/v7072814.

Blouin AG, Biccheri R, Khalifa ME, Pearson MN, Pollini CP, Hamiaux C, et al. Characterization of actinidia virus 1, a new member of the family Closteroviridae encoding a thaumatin-like protein. Arch Virol. 2018;163:229-34. https://doi.org/10.1007/s00705-017-3610-z.

Bortolamiol D, Pazhouhandeh M, Marrocco K, Genschik P, Ziegler-Graff V. The polerovirus $F$ box protein P0 targets ARGONAUTE1 to suppress RNA silencing. Curr Biol. 2007;17(18):1615-21. https://doi.org/10.1016/j.cub. 2007.07.061.

Boubourakas IN, Avgelis AD, Kyriakopoulou PE, Katis NI. Occurrence of yellowing viruses (beet pseudo-yellows virus, cucurbit yellow stunting disorder virus and cucurbit aphid-borne yellows virus) affecting cucurbits in Greece. Plant Pathol. 2006;55(2):276-83. https://doi.org/10.1111/j. 1365-3059.2006.01341.x.

Brodersen P, Sakvarelidze-Achard L, Bruun-Rasmussen M, Dunoyer P, Yamamoto YY, Sieburth L, et al. Widespread translational inhibition by plant miRNAs and siRNAs. Science. 2008;320(5880):1185-90. https://doi.org/ 10.1126/science.1159151.

Buchmann RC, Asad S, Wolf JN, Mohannath G, Bisaro DM. Geminivirus AL2 and L2 proteins suppress transcriptional gene silencing and cause genomewide reductions in cytosine methylation. J Virol. 2009;83(10):5005-13. https://doi.org/10.1128/JVI.01771-08.

Burgyán J, Havelda Z. Viral suppressors of RNA silencing. Trends Plant Sci. 2011;16(5):265-72. https://doi.org/10.1016/j.tplants.2011.02.010.

Calil IP, Fontes EPB. Plant immunity against viruses: antiviral immune receptors in focus. Ann Bot. 2017;1 19(5):711-23. https://doi.org/10.1093/aob/ mcw200.

Canizares MC, Taylor KM, Lomonossoff GP. Surface-exposed C-terminal amino acids of the small coat protein of cowpea mosaic virus are required for suppression of silencing. J Gen Virol. 2004;85(11):3431-5. https://doi. org/10.1099/vir.0.80454-0.

Canizares MC, Navas-Castillo J, Moriones E. Multiple suppressors of RNA silencing encoded by both genomic RNAs of the crinivirus, tomato chlorosis virus. Virology. 2008;379(1):168-74. https://doi.org/10.1016/j.virol.2008. 06.020.

Canto T, Uhrig JF, Swanson M, Wright KM, MacFarlane SA. Translocation of tomato bushy stunt virus p19 protein into the nucleus by ALY proteins compromises its silencing suppressor activity. J Virol. 2006;80(18):906472. https://doi.org/10.1128/JVI.00953-06.

Carbonell A, Carrington JC. Antiviral roles of plant ARGONAUTES. Curr Opin Plant Biol. 2015;27:111-7. https://doi.org/10.1016/j.pbi.2015.06.013.

Castillo-Gonzalez C, Liu X, Huang C, Zhao C, Ma Z, Hu T, et al. Geminivirusencoded TrAP suppressor inhibits the histone methyltransferase SUVH4/KYP to counter host defense. Elife. 2015;4: e06671. https://doi. org/10.7554/eLife.06671.

Chapman EJ, Prokhnevsky Al, Gopinath K, Dolja W, Carrington JC. Viral RNA silencing suppressors inhibit the microRNA pathway at an intermediate step. Genes Dev. 2004;18:1179-86. https://doi.org/10.1101/gad.12012 04.

Chen J, Li WX, Xie D, Peng JR, Ding SW. Viral virulence protein suppresses RNA silencing-mediated defense but upregulates the role of microrna in host gene expression. Plant Cell. 2004;16(5):1302-13. https://doi.org/10. 1105/tpc.018986.

Chen HY, Yang J, Lin C, Yuan YA. Structural basis for RNA-silencing suppression by tomato aspermy virus protein 2b. EMBO Rep. 2008;9(8):754-60. https://doi.org/10.1038/embor.2008.118.

Chen S, Sun X, Shi Y, Wei Y, Han X, Li H, et al. Cucurbit chlorotic yellows virus p22 protein interacts with cucumber SKP1LB1 and its F-box-like motif is crucial for silencing suppressor activity. Viruses. 2019;11(9):818. https:// doi.org/10.3390/v11090818.

Cheng X, Wang A. The potyvirus silencing suppressor protein VPg mediates degradation of SGS3 via ubiquitination and autophagy pathways. J Virol. 2017;91(1):e01478-16. https://doi.org/10.1128/JVI.01478-16. 
Chiba S, Hleibieh K, Delbianco A, Klein E, Ratti C, Ziegler-GraffV, et al. The benyvirus RNA silencing suppressor is essential for long-distance movement, requires both zinc-finger and NoLS basic residues but not a nucleolar localization for its silencing-suppression activity. Mol Plant Microb Interact. 2013;26(2):168-81. https://doi.org/10.1094/MPMI-06-12-0142-R.

Chiu MH, Chen IH, Baulcombe DC, Tsai CH. The silencing suppressor p25 of potato virus $\mathrm{X}$ interacts with Argonaute1 and mediates its degradation through the proteasome pathway. Mol Plant Pathol. 2010;1 1(5):641-9. https://doi.org/10.1111/j.1364-3703.2010.00634.x.

Csorba T, Burgyán J. Antiviral silencing and suppression of gene silencing in plants. In: Wang A, Zhou X, editors. Current research topics in plant virology. Cham: Springer; 2016. p. 1-33. https://doi.org/10.1007/ 978-3-319-32919-2 1.

Csorba T, Bovi A, Dalmay T, Burgyan J. The p122 subunit of tobacco mosaic virus replicase is a potent silencing suppressor and compromises both small interfering RNA- and microRNA-mediated pathways. J Virol. 2007;81(21):11768-80. https://doi.org/10.1128/JVI.01230-07.

Csorba T, Kontra L, Burgyan J. Viral silencing suppressors: Tools forged to fine-tune host-pathogen coexistence. Virology. 2015;479-480:85-103. https://doi.org/10.1016/j.virol.2015.02.028.

Cuellar WJ, Tairo F, Kreuze JF, Valkonen JPT. Analysis of gene content in sweet potato chlorotic stunt virus RNA1 reveals the presence of the p22 RNA silencing suppressor in only a few isolates: implications for viral evolution and synergism. J Gen Virol. 2008;89(2):573-82. https://doi.org/10. 1099/vir.0.83471-0.

Cuellar WJ, Kreuze JF, Rajamäki M-L, Cruzado KR, Untiveros M, Valkonen JPT. Elimination of antiviral defense by viral RNase III. Proc Nat Acad Sci U S A. 2009;106(25):10354-8. https://doi.org/10.1073/pnas.0806042106.

Cui H, Tsuda K, Parker JE. Effector-triggered immunity: from pathogen perception to robust defense. Annu Rev Plant Biol. 2015;66:487-511. https:// doi.org/10.1146/annurev-arplant-050213-040012.

Daròs JA. Viral suppressors: combatting RNA silencing. Nat Plant. 2017;3:17098. https://doi.org/10.1038/nplants.2017.98.

Del Toro FJ, Donaire L, Aguilar E, Chung B-N, Tenllado F, Canto T. Potato virus Y HCPro suppression of antiviral silencing in Nicotiana benthamiana plants correlates with its ability to bind in vivo to 21- and 22-nucleotide small RNAs of viral sequence. J Virol. 2017;91(12):e00367-17. https://doi. org/10.1128/JVI.00367-17.

Delfosse VC, Agrofoglio YC, Casse MF, Kresic IB, Hopp HE, Ziegler-GraffV, et al. The PO protein encoded by cotton leafroll dwarf virus (CLRDV) inhibits local but not systemic RNA silencing. Virus Res. 2014;180:70-5. https:// doi.org/10.1016/j.virusres.2013.12.018.

Deng XG, Peng XJ, Zhu F, Chen YJ, Zhu T, Qin SB, et al. A critical domain of sweet potato chlorotic fleck virus nucleotide-binding protein ( $\mathrm{NaBp}$ ) for RNA silencing suppression, nuclear localization and viral pathogenesis. Mol Plant Pathol. 2015;16(4):365-75. https://doi.org/10.1111/mpp. 12186.

Derrien B, Baumberger N, Schepetilnikov M, Viotti C, De Cillia J, Ziegler-Graff $V$, et al. Degradation of the antiviral component ARGONAUTE1 by the autophagy pathway. Proc Nat Acad Sci U S A. 2012;109(39):15942-6. https://doi.org/10.1073/pnas.1209487109.

Derrien B, Clavel M, Baumberger N, Iki T, Sarazin A, Hacquard T, et al. A suppressor screen for $\mathrm{AGO} 1$ degradation by the viral F-box PO protein uncovers a role for AGO DUF1785 in sRNA duplex unwinding. Plant Cell. 2018;30(6):1353-74. https://doi.org/10.1105/tpc.18.00111.

Dey KK, Borth WB, Melzer MJ, Wang ML, Hu JS. Analysis of pineapple mealybug wilt associated virus- 1 and -2 for potential RNA silencing suppressors and pathogenicity factors. Viruses. 2015;7(3):969-95. https://doi.org/10. 3390/v7030969.

Dey KK, Green JC, Melzer M, Borth W, Hu JS. Mealybug wilt of pineapple and associated viruses. Horticulturae. 2018;4(4):52. https://doi.org/10.3390/ horticulturae4040052.

Dey KK, Sugikawa J, Kerr C, Melzer MJ. Air potato (Dioscorea bulbifera) plants displaying virus-like symptoms are co-infected with a novel potyvirus and a novel ampelovirus. Virus Genes. 2019;55:117-21. https://doi.org/ 10.1007/s11262-018-1616-6.

Diaz-Pendon JA, Li F, Li WX, Ding SW. Suppression of antiviral silencing by cucumber mosaic virus $2 \mathrm{~b}$ protein in Arabidopsis is associated with drastically reduced accumulation of three classes of viral small interfering RNAs. Plant Cell. 2007;19(6):2053-63. https://doi.org/10.1105/tpc. 106.047449 .
Du Z, Xiao D, Wu J, Jia D, Yuan Z, Liu Y, et al. P2 of rice stripe virus (RSV) interacts with OsSGS3 and is a silencing suppressor. Mol Plant Pathol. 2011;12(8):808-14. https://doi.org/10.1111/j.1364-3703.2011.00716.x.

Duan C-G, Fang Y-Y, Zhou B-J, Zhao J-H, Hou W-N, Zhu H, et al. Suppression of Arabidopsis ARGONAUTE1-mediated slicing, transgene-induced RNA silencing, and DNA methylation by distinct domains of the cucumber mosaic virus 2b protein. Plant Cell. 2012;24(1):259-74. https://doi.org/ 10.1105/tpc.111.092718.

Dubiella U, Serrano I. The ubiquitin proteasome system as a double agent in plant-virus interactions. Plants. 2021;10(5):928. https://doi.org/10.3390/ plants10050928.

Dunoyer P, Lecellier CH, Parizotto EA, Himber C, Voinnet O. RETRACTED: Probing the microRNA and small interfering RNA pathways with virusencoded suppressors of RNA silencing. Plant Cell. 2004;16(5):1235-50. https://doi.org/10.1105/tpc.020719.

Endres MW, Gregory BD, Gao Z, Foreman AW, Mlotshwa S, Ge X, et al. Two plant viral suppressors of silencing require the ethylene-inducible host transcription factor RAV2 to block RNA silencing. PLoS Pathog. 2010;6:e1000729. https://doi.org/10.1371/journal.ppat.1000729.

Fagoaga C, Pensabene-Bellavia G, Moreno P, Navarro L, Flores R, Pena L. Ectopic expression of the p23 silencing suppressor of Citrus tristeza virus differentially modifies viral accumulation and tropism in two transgenic woody hosts. Mol Plant Pathol. 2011;12(9):898-910. https://doi.org/10 1111/j.1364-3703.2011.00722.x.

Fernandez-Calvino L, Martínez-Priego L, Szabo EZ, Guzman-Benito I, Gonzalez I, Canto T, et al. Tobacco rattle virus $16 \mathrm{~K}$ silencing suppressor binds ARGONAUTE 4 and inhibits formation of RNA silencing complexes. J Gen Virol. 2016;97(1):246-57. https://doi.org/10.1099/jgv.0.000323.

Fontana A, Piscopo A, De Bruno A, Tiberini A, Muzzalupo I, Albanese G. Impact of olive leaf yellowing associated virus on olive (Olea europaea L.) Oil. Eur J Lipid Sci Technol. 2019;121:1800472. https://doi.org/10.1002/ejlt. 201800472

Fuchs M, Bar-Joseph M, Candresse T, Maree HJ, Martelli GP, Melzer MJ, et al. ICTV virus taxonomy profile: Closteroviridae. J Gen Virol. 2020;101(4):364-5. https://doi.org/10.1099/jgv.0.001397.

Fuellgrabe MW, Boonrod K, Jamous R, Moser M, Shiboleth Y, Krczal G, et al. Expression, purification and functional characterization of recombinant zucchini yellow mosaic virus HC-Pro. Protein Expr Purif. 2011;75(1):40-5. https://doi.org/10.1016/j.pep.2010.07.008.

Fusaro AF, Correa RL, Nakasugi K, Jackson C, Kawchuk L, Vaslin MFS, et al. The enamovirus PO protein is a silencing suppressor which inhibits local and systemic RNA silencing through AGO1 degradation. Virology. 2012;426(2):178-87. https://doi.org/10.1016/j.virol.2012.01.026.

Gaffar FY, Koch A. Catch me if you can! RNA silencing-based improvement of antiviral plant immunity. Viruses. 2019;11(7):673. https://doi.org/10. 3390/v11070673.

Genoves A, Navarro JA, Pallas V. Functional analysis of the five melon necrotic spot virus genome-encoded proteins. J Gen Virol. 2006;87(8):2371-80. https://doi.org/10.1099/vir.0.81793-0.

Giner A, Lakatos L, Garcıa-Chapa M, López-Moya J, Burgyán J. Viral Protein inhibits RISC activity by Argonaute binding through conserved WG motifs. PLoS Pathog. 2010;6:e1000996. https://doi.org/10.1371/journal. ppat.1000996.

Glick E, Zrachya A, Levy Y, Mett A, Gidoni D, Belausov E, et al. Interaction with host SGS3 is required for suppression of RNA silencing by tomato yellow leaf curl virus V2 protein. Proc Nat Acad Sci U S A. 2008;105(1):15761. https://doi.org/10.1073/pnas.0709036105.

Goswami S, Sahana N, Pandey V, Doblas P, Jain RK, Palukaitis P, et al. Interference in plant defense and development by non-structural protein NSs of groundnut bud necrosis virus. Virus Res. 2012;163(1):368-73. https:// doi.org/10.1016/j.virusres.2011.08.016.

Goto K, Kobori T, Kosaka Y, Natsuaki T, Masuta C. Characterization of silencing suppressor $2 \mathrm{~b}$ of cucumber mosaic virus based on examination of its small RNA-binding abilities. Plant Cell Physiol. 2007;48(7):1050-60. https://doi.org/10.1093/pcp/pcm074.

Gouveia P, Nolasco G. The p19.7 RNA silencing suppressor from grapevine leafroll-associated virus 3 shows different levels of activity across phylogenetic groups. Virus Genes. 2012;45:333-9. https://doi.org/10.1007/ s11262-012-0772-3.

Gouveia P, Dandlen S, Costa Â, Marques N, Nolasco G. Identification of an RNA silencing suppressor encoded by grapevine leafroll-associated 
virus 3. Eur J Plant Pathol. 2012;133:237-45. https://doi.org/10.1007/ s10658-011-9876-1.

Gouveia BC, Calil IP, Machado JPB, Santos AA, Fontes EPB. Immune receptors and co-receptors in antiviral innate immunity in plants. Front Microbiol. 2017;7:2139. https://doi.org/10.3389/fmicb.2016.02139.

Guerrero J, Regedanz E, Lu L, Ruan J, Bisaro DM, Sunter G. Manipulation of the plant host by the geminivirus AC2/C2 protein, a central player in the infection cycle. Fron Plant Sci. 2020;11:591. https://doi.org/10.3389/fpls. 2020.00591

Guo HS, Ding SW. A viral protein inhibits the long range signaling activity of the gene silencing signal. EMBO J. 2002;21:398-407. https://doi.org/10. 1093/emboj/21.3.398.

Guo H, Song X, Xie C, Huo Y, Zhang F, Chen $X$, et al. Rice yellow stunt rhabdovirus protein 6 suppresses systemic RNA silencing by blocking RDR6-mediated secondary siRNA synthesis. Mol Plant Microbe Interact. 2013;26(8):927-36. https://doi.org/10.1094/MPMI-02-13-0040-R.

Haas G, Azevedo J, Moissiard G, Geldreich A, Himber C, Bureau M, et al. Nuclear import of $\mathrm{CaMV}$ p6 is required for infection and suppression of the RNA silencing factor DRB4. EMBO J. 2008;27:2102-12. https://doi.org/10. 1038/emboj.2008.129.

Hajeri S, Killiny N, El-Mohtar C, Dawson WO, Gowda S. Citrus tristeza virusbased RNAi in citrus plants induces gene silencing in Diaphorina citri, a phloem-sap sucking insect vector of citrus greening disease (Huanglongbing). J Biotechnol. 2014;176:42-9. https://doi.org/10.1016/j.jbiot ec.2014.02.010.

Hao X, Lu A, Sokal N, Bhagwat B, Leung E, Mao R, et al. Cucumber necrosis virus p20 is a viral suppressor of RNA silencing. Virus Res. 2011;155(2):423-32. https://doi.org/10.1016/j.virusres.2010.11.011.

Hatsugai N, Igarashi D, Mase K, Lu Y, Tsuda Y, Chakravarthy S, et al. A plant effector-triggered immunity signaling sector is inhibited by patterntriggered immunity. EMBO J. 2017;36:2758-69. https://doi.org/10. 15252/embj.201796529.

He Y, Yang Z, Hong N, Wang G, Ning G, Xu W. Deep sequencing reveals a novel closterovirus associated with wild rose leaf rosette disease. Mol Plant Pathol. 2015;16:449-58. https://doi.org/10.1111/mpp.12202.

He J, Ye W, Choi DS, Wu B, Zhai Y, Guo B, et al. Structural analysis of Phytophthora suppressor of RNA silencing 2 (PSR2) reveals a conserved modular fold contributing to virulence. Proc Nat Acad Sci U S A. 2019;116(16):8054-9. https://doi.org/10.1073/pnas.1819481116.

Hedil M, Sterken MG, de Ronde D, Lohuis D, Kormelink R. Analysis of tospovirus NSs proteins in suppression of systemic silencing. PLOS ONE. 2015:10:e0134517. https://doi.org/10.1371/journal.pone.0134517.

Hemmes H, Lakatos L, Goldbach R, Burgyan J, Prins M. The NS3 protein of rice hoja blanca tenuivirus suppresses RNA silencing in plant and insect hosts by efficiently binding both siRNAs and miRNAs. RNA. 2007:13:1079-89. https://doi.org/10.1261/rna.444007.

Hernández-Rodríguez L, Nápoles Borrero L, Pérez Vicente L, Concepción Laffitte OV, Cid Ruiz M, Alvares Llanes Y, et al. Infección de pineapple mealybug wilt-associated virus 1, 2 y 3 en plantas de piña, híbrido'MDZ'en Ciego de Ávila. Centro Agrícola. 2017;44(2):52-60.

Hu SF, Wei WL, Hong SF, Fang RY, Wu HY, Lin PC, et al. Investigation of the effects of P1 on HC-pro-mediated gene silencing suppression through genetics and omics approaches. Bot Stud. 2020;61:22. https://doi.org/ 10.1186/s40529-020-00299-X.

Huh SU, Choi LM, Lee G-J, Kim YJ, Paek K-H. Capsicum annuum WRKY transcription factor d (CaWRKYd) regulates hypersensitive response and defense response upon tobacco mosaic virus infection. Plant Sci. 2012;197:50-8. https://doi.org/10.1016/j.plantsci.2012.08.013.

Ismayil A, Haxim Y, Wang Y, Li H, Qian L, Han T, et al. Cotton leaf curl multan virus $C 4$ protein suppresses both transcriptional and post-transcriptional gene silencing by interacting with SAM synthetase. PLoS Pathog. 2018:14:e1007282. https://doi.org/10.1371/journal.ppat.1007282.

Isogai M, Muramatu S, Watanabe M, Yoshikawa N. Complete nucleotide sequence and latency of a novel blueberry-infecting closterovirus. J Gen Plant Pathol. 2013;79:123-7. https://doi.org/10.1007/ s10327-013-0431-0.

Ito T, Nakaune R. Molecular characterization of a novel putative ampelovirus tentatively named grapevine leafroll-associated virus 13. Arch Virol. 2016;161:2555-9. https://doi.org/10.1007/s00705-016-2914-8.
Ito T, Sato A, Suzaki K. An assemblage of divergent variants of a novel putative closterovirus from American persimmon. Virus Genes. 2015;51:105-11. https://doi.org/10.1007/s11262-015-1202-0.

Ivanov KI, Eskelin K, Basic M, De S, Lohmus A, Varjosalo M, et al. Molecular insights into the function of the viral RNA silencing suppressor HCPro. Plant J. 2016;85(1):30-45. https://doi.org/10.1111/tpj.13088.

Jackel JN, Buchmann RC, Singhal U, Bisaro DM. Analysis of geminivirus AL2 and L2 proteins reveals a novel AL2 silencing suppressor activity. J Virol. 2015:89:3176-87. https://doi.org/10.1128/JVI.02625-14

Jamous RM, Boonrod K, Fuellgrabe MW, Ali-Shtayeh MS, Krczal G, Wassenegger M. The helper component-proteinase of the zucchini yellow mosaic virus inhibits the Hua Enhancer 1 methyltransferase activity in vitro. J Gen Virol. 2011;92(9):2222-6. https://doi.org/10.1099/vir.0.031534-0.

Jauvion V, Elmayan T, Vaucheret $\mathrm{H}$. The conserved RNA trafficking proteins HPR 1 and TEX 1 are involved in the production of endogenous and exogenous small interfering RNA in Arabidopsis. Plant Cell. 2010;22(8):2697-709. https://doi.org/10.1105/tpc.110.076638.

Jelkmann W, Mikona C, Turturo C, Navarro B, Rott ME, Menzel W, et al. Molecular characterization and taxonomy of grapevine leafrollassociated virus 7. Arch Virol. 2012;157:359-62. https://doi.org/10.1007/ s00705-011-1176-8.

Jin Y, Zhao J-H, Guo H-S. Recent advances in understanding plant antiviral RNAi and viral suppressors of RNAi. Curr Opin Virol. 2021;46:65-72. https://doi.org/10.1016/j.coviro.2020.12.001.

Jones RAC. Global plant virus disease pandemics and epidemics. Plants. 2021;10(2):233. https://doi.org/10.3390/plants10020233.

Jones JDG, Dangl JL. The plant immune system. Nature. 2006:444:323-9. https://doi.org/10.1038/nature05286.

Kamle M, Borah R, Bora H, Jaiswal AK, Singh RK, Kumar P. Systemic acquired resistance (SAR) and induced systemic resistance (ISR): role and mechanism of action against phytopathogens. In: Hesham AL, Upadhyay R, Sharma G, Manoharachary C, Gupta V, editors. Fungal biotechnology and bioengineering. Cham: Springer; 2020. p. 457-70. https://doi.org/ 10.1007/978-3-030-41870-0_20.

Karasev AV, Nikolaeva OV, Lee RF, Wisler GC, Duffus JE, Dawson WO. Characterization of the beet yellow stunt virus coat protein gene. Phytopathology. 1998;88(10):1040-5. https://doi.org/10.1094/PHYTO.1998.88.10. 1040.

Karran RA, Sanfacon H. Tomato ringspot virus coat protein binds to ARGONAUTE 1 and suppresses the translation repression of a reporter gene. Mol Plant Microbe Interact. 2014;27(9):933-43. https://doi.org/10.1094/ MPMI-04-14-0099-R.

Kasschau KD, Xie Z, Allen E, Llave C, Chapman EJ, Krizan KA, et al. P1/HC-Pro, a viral suppressor of RNA silencing, interferes with Arabidopsis development and miRNA function. Dev Cell. 2003;4(2):205-17. https://doi.org/ 10.1016/S1534-5807(03)00025-X.

Kataya ARA, Suliman MNS, Kalantidis K, Livieratos IC. Cucurbit yellow stunting disorder virus p25 is a suppressor of post-transcriptional gene silencing. Virus Res. 2009;145(1):48-53. https://doi.org/10.1016/j.virusres.2009.06. 010.

Kenesi E, Carbonell A, Lózsa R, Vértessy B, Lakatos L. A viral suppressor of RNA silencing inhibits ARGONAUTE 1 function by precluding target RNA binding to pre-assembled RISC. Nucleic Acids Res. 2017:45(13):7736-50. https://doi.org/10.1093/nar/gkx379.

Kirk M, Temple SR, Summers CG, Wilson LT. Transmission efficiencies of fieldcollected aphid (Homoptera: Aphididae) vectors of beet yellows virus. J Econ Entomol. 1991;84(2):638-43. https://doi.org/10.1093/jee/84.2.638.

Kreuze JF, Savenkov El, Valkonen JPT. Complete genome sequence and analyses of the subgenomic RNAs of sweet potato chlorotic stunt virus reveal several new features for the genus Crinivirus. J Virol. 2002;76(18):9260-70. https://doi.org/10.1128/JVI.76.18.9260-9270.2002.

Kreuze JF, Savenkov El, Cuellar W, Li X, Valkonen JP. Viral class 1 RNase III involved in suppression of RNA silencing. J Virol. 2005;79(11):7227-38. https://doi.org/10.1128/JVI.79.11.7227-7238.2005.

Kubota K, Ng JCK. Lettuce chlorosis virus p23 suppresses RNA silencing and induces local necrosis with increased severity at raised temperatures. Phytopathology. 2016;106(6):653-62. https://doi.org/10.1094/ PHYTO-09-15-0219-R.

Kubota K, Tsuda S, Tamai A, Meshi T. Tomato mosaic virus replication protein suppresses virus-targeted posttranscriptional gene silencing. J Virol. 
2003;77(20):11016-26. https://doi.org/10.1128/JVI.77.20.11016-11026. 2003.

Lacombe S, Bangratz M, Vignols F, Brugidou C. The rice yellow mottle virus P1 protein exhibits dual functions to suppress and activate gene silencing. Plant J. 2010;61(3):371-82. https://doi.org/10.1111/j.1365-313X.2009. 04062.x.

Lakatos L, Csorba T, Pantaleo V, Chapman EJ, Carrington JC, Liu YP, et al. Small RNA binding is a common strategy to suppress RNA silencing by several viral suppressors. EMBO J. 2006;25(12):2768-80. https://doi.org/ 10.1038/sj.emboj.7601164.

Landeo-Rios Y, Navas-Castillo J, Moriones E, Canizares MC. The p22 RNA silencing suppressor of the crinivirus tomato chlorosis virus is dispensable for local viral replication but important for counteracting an antiviral RDR6mediated response during systemic infection. Viruses. 2016a;8(7):182. https://doi.org/10.3390/v8070182.

Landeo-Rios Y, Navas-Castillo J, Moriones E, Canizares MC. The p22 RNA silencing suppressor of the crinivirus tomato chlorosis virus preferentially binds long dsRNAs preventing them from cleavage. Virology. 2016b;488:129-36. https://doi.org/10.1016/j.virol.2015.11.008.

Landeo-Rios Y, Navas-Castillo J, Moriones E, Canizares MC. The heterologous expression of the p22 RNA silencing suppressor of the crinivirus tomato chlorosis virus from tobacco rattle virus and potato virus $X$ enhances disease severity but does not complement suppressor-defective mutant viruses. Viruses. 2017;9(12):358. https://doi.org/10.3390/v9120 358.

Lax C, Tahiri G, Patiño-Medina JA, Cánovas-Márquez JT, Pérez-Ruiz JA, OsorioConcepción M, et al. The evolutionary significance of RNAi in the fungal kingdom. Int J Mol Sci. 2020;21 (24):9348. https://doi.org/10.3390/ijms2 1249348.

Lee $\mathrm{CH}$, Carroll BJ. Evolution and diversification of small RNA pathways in flowering plants. Plant Cell Physiol. 2018;59(11):2169-87. https://doi. org/10.1093/pcp/pcy 167 .

Li F, Wang A. RNA-targeted antiviral immunity: more than just RNA silencing. Trends Microbiol. 2019;27(9):792-805. https://doi.org/10.1016/j.tim. 2019.05.007.

Li F, Huang C, Li Z, Zhou X. Suppression of RNA silencing by a plant DNA virus satellite requires a host calmodulin-like protein to repress RDR6 expression. PLoS Pathog. 2014;10:e1003921. https://doi.org/10.1371/journal. ppat. 1003921.

Li M, Zhang J, Feng M, Wang X, Luo C, Wang Q, et al. Characterization of silencing suppressor p24 of grapevine leafroll-associated virus 2. Mol Plant Pathol. 2018;19(2):355-68. https://doi.org/10.1111/mpp.12525.

Li Z, He Y, Luo T, Zhang X, Wan H, Ur Rehman A, et al. Identification of key residues required for RNA silencing suppressor activity of p23 protein from a mild strain of citrus tristeza virus. Viruses. 2019;11(9):782. https:// doi.org/10.3390/v11090782.

Liu Q, Guo R, Li M, Feng M, Wang X, Wang Q, et al. Critical regions and residues for self-interaction of grapevine leafroll-associated virus 2 protein p24. Virus Res. 2016;220:57-63. https://doi.org/10.1016/j.virusres.2016.04. 010.

Liu S, Wang C, Liu X, Navas-Castillo J, Zang L, Fan Z, et al. Tomato chlorosis virus-encoded p22 suppresses auxin signalling to promote infection via interference with SKP1-Cullin-F-box ${ }^{\text {TR1 }}$ complex assembly. Plant Cell Environ. 2021;44(9):3155-72. https://doi.org/10.1111/pce.14125.

Lozsa R, Csorba T, Lakatos L, Burgyan J. Inhibition of 3' modification of small RNAs in virus-infected plants require spatial and temporal co-expression of small RNAs and viral silencing-suppressor proteins. Nucleic Acids Res. 2008;36(12):4099-107. https://doi.org/10.1093/nar/gkn365.

Lu R, Folimonov A, Shintaku M, Li WX, Falk BW, Dawson WO, et al. Three distinct suppressors of RNA silencing encoded by a 20-kb viral RNA genome. Proc Nat Acad Sci U S A. 2004;101(44):15742-7. https://doi.org/10.1073/ pnas.0404940101

Lukhovitskaya NI, Vetukuri RR, Sama I, Thaduri S, Solovyev AG, Savenkov El. A viral transcription factor exhibits antiviral RNA silencing suppression activity independent of its nuclear localization. J Gen Virol. 2014:95(12):2831-7. https://doi.org/10.1099/vir.0.067884-0.

Mandadi KK, Scholthof KBG. Plant immune responses against viruses: how does a virus cause disease? Plant Cell. 2013;25(5):1489-505. https://doi. org/10.1105/tpc.113.111658.

Mangwende T, Wang ML, Borth W, Hu J, Moore PH, Mirkov TE, et al. The PO gene of sugarcane yellow leaf virus encodes an RNA silencing suppressor with unique activities. Virology. 2009;384(1):38-50. https:// doi.org/10.1016/j.virol.2008.10.034.

Mann KS, Johnson KN, Carroll BJ, Dietzgen RG. Cytorhabdovirus P protein suppresses RISC-mediated cleavage and RNA silencing amplification in planta. Virology. 2016;490:27-40. https://doi.org/10.1016/j.virol.2016. 01.003.

Maree HJ, Almeida RPP, Bester R, Chooi KM, Cohen D, Dolja W, et al. Grapevine leafroll-associated virus 3. Front Microbiol. 2013;4:82. https://doi.org/10. 3389/fmicb.2013.00082.

Martelli GP. A brief historical account of the family Closteroviridae. In: Catara AF, Bar-Joseph M, Licciardello G, editors. Citrus Tristeza virus: methods and protocols. New York: Humana Press; 2019. p. 7-13. https://doi.org/ 10.1007/978-1-4939-9558-5_2.

Martelli G, Ghanem-Sabanadzovic NA, Agranovsky A, Rwahnih MA, Dolja V Dovas C, et al. Taxonomic revision of the family Closteroviridae with special reference to the grapevine leafroll-associated members of the genus ampelovirus and the putative species unassigned to the family. J Plant Pathol. 2012;94(1):7-19.

Martín G, Cuadrado IM, Janssen D. Bean yellow disorder virus: parameters of transmission by Bemisia tabaci and host plant range. Insect Sci. 2011;18(1):50-6. https://doi.org/10.1111/j.1744-7917.2010.01385.x.

Martinez-Priego L, Donaire L, Barajas D, Llave C. Silencing suppressor activity of the tobacco rattle virus-encoded 16-kDa protein and interference with endogenous small RNA-guided regulatory pathways. Virology. 2008;376(2):346-56. https://doi.org/10.1016/j.virol.2008.03.024.

Martinez-Turino S, Hernandez C. Inhibition of RNA silencing by the coat protein of pelargonium flower break virus: distinctions from closely related suppressors. J Gen Virol. 2009;90(2):519-25. https://doi.org/10. 1099/vir.0.006098-0

Mashiko T, Wang W-Q, Hartono S, Suastica G, Neriya Y, Nishigawa H, et al. The p27 open reading frame of tomato infectious chlorosis virus encodes a suppressor of RNA silencing. J Gen Plant Pathol. 2019;85:301-5. https:// doi.org/10.1007/s10327-019-00850-0.

Mathioudakis MM, Veiga RSL, Canto T, Medina V, Mossialos D, Makris AM, et al. Pepino mosaic virus triple gene block protein 1 (TGBp1) interacts with and increases tomato catalase 1 activity to enhance virus accumulation. Mol Plant Pathol. 2013;14(6):589-601. https://doi.org/10.1111/mpp. 12034.

Mathioudakis MM, Rodriguez-Moreno L, Sempere RN, Aranda MA, Livieratos I. Multifaceted capsid proteins: multiple interactions suggest multiple roles for pepino mosaic virus capsid protein. Mol Plant Microbe Interact. 2014;27(12):1356-69. https://doi.org/10.1094/MPMI-07-14-0195-R.

Medina V, Sudarshana MR, Tian T, Ralston KS, Yeh HH, Falk BW. The lettuce infectious yellows virus (LIYV)-encoded p26 is associated with plasmalemma deposits within LIYV-infected cells. Virology. 2005;333(2):367-73. https://doi.org/10.1016/j.virol.2005.01.012.

Mekuria TA, Zhang S, Eastwell KC. Rapid and sensitive detection of little cherry virus 2 using isothermal reverse transcription-recombinase polymerase amplification. J Virol Methods. 2014;205:24-30. https://doi.org/10. 1016/j.jviromet.2014.04.015.

Melnyk CW, Molnar A, Baulcombe DC. Intercellular and systemic movement of RNA silencing signals. EMBO J. 2011;30:3553-63. https://doi.org/10. 1038/emboj.2011.274.

Melzer M, Ayin C, Sugano J, Uchida J, Kawate M, Borth W, et al. Differentiation and distribution of cordyline viruses 1-4 in Hawaiian ti plants (Cordyline fruticosa L.). Viruses. 2013a;5(7):1655-63. https://doi.org/10.3390/v5071 655.

Melzer MJ, Sugano JS, Uchida JY, Borth WB, Kawate MK, Hu JS. Molecular characterization of closteroviruses infecting Cordyline fruticosa L. in Hawaii. Front Microbiol. 2013b;4:39. https://doi.org/10.3389/fmicb.2013.00039.

Meng C, Chen J, Peng J, Wong SM. Host-induced avirulence of hibiscus chlorotic ringspot virus mutants correlates with reduced gene-silencing suppression activity. J Gen Virol. 2006;87(2):451-9. https://doi.org/10. 1099/vir.0.81578-0.

Mengistu AA, Tenkegna TA. The role of miRNA in plant-virus interaction: a review. Mol Biol Rep. 2021;48:2853-61. https://doi.org/10.1007/ s11033-021-06290-4.

Merai Z, Kerenyi Z, Molnar A, Barta E, Valoczi A, Bisztray G, et al. Aureusvirus p14 is an efficient RNA silencing suppressor that binds double-stranded RNAs without size specificity. JVirol. 2005;79(11):7217-26. https://doi. org/10.1128/JVI.79.11.7217-7226.2005. 
Merai Z, Kerenyi Z, Kertesz S, Magna M, Lakatos L, Silhavy D. Double-stranded RNA binding may be a general plant RNA viral strategy to suppress RNA silencing. J Virol. 2006;80(12):5747-56. https://doi.org/10.1128/JVl. 01963-05.

Mermigka G, Verret F, Kalantidis K. RNA silencing movement in plants. J Integr Plant Biol. 2016;58(4):328-42. https://doi.org/10.1111/jipb.12423.

Mitiouchkina TY, Firsov AP, Titova SM, Pushin AS, Shulga OA, Dolgov SV. Different approaches to produce transgenic virus B resistant chrysanthemum. Agronomy. 2018;8(3):28. https://doi.org/10.3390/agronomy80 30028.

Moreno P, Ambros S, Albiach-Marti MR, Guerri J, Pena L. Citrus tristeza virus: a pathogen that changed the course of the citrus industry. Mol Plant Pathol. 2008;9(2):251-68. https://doi.org/10.1111/j.1364-3703.2007. 00455.x.

Muhammad T, Zhang F, Zhang Y, Liang Y. RNA interference: a natural immune system of plants to counteract biotic stressors. Cells. 2019;8(1):38. https://doi.org/10.3390/cells8010038.

Müller M, Fazi F, Ciaudo C. Argonaute proteins: from structure to function in development and pathological cell fate determination. Front Cell Dev Biol. 2020;7:360. https://doi.org/10.3389/fcell.2019.00360.

Muñoz Baena L, Gutiérrez Sánchez PA, Marín MM. Secuenciación del genoma completo del potato yellow vein virus (PYVV) en tomate (Solanum lycopersicum) en Colombia. Acta Biol Colomb. 2017;22(1):5-17. https:// doi.org/10.15446/abc.v22n1.59211.

Naidu R, Rowhani A, Fuchs M, Golino D, Martelli GP. Grapevine leafroll: a complex viral disease affecting a high-value fruit crop. Plant Dis. 2014;98(9):1172-85. https://doi.org/10.1094/PDIS-08-13-0880-FE.

Nakahara KS, Masuta C, Yamada S, Shimura H, Kashihara Y, Wada TS, et al. Tobacco calmodulin-like protein provides secondary defense by binding to and directing degradation of virus RNA silencing suppressors. Proc Nat Acad Sci U S A. 2012;109(25):10113-8. https://doi.org/10.1073/ pnas.1201628109.

Navarro L, Jay F, Nomura K, He SY, Voinnet O. Suppression of the microRNA pathway by bacterial effector proteins. Science. 2008;321(5891):964-7. https://doi.org/10.1126/science.1159505.

Niehl A, Heinlein M. Perception of double-stranded RNA in plant antiviral immunity. Mol Plant Pathol. 2019;20(9):1203-10. https://doi.org/10. 1111/mpp.12798.

Niehl A, Wyrsch I, Boller T, Heinlein M. Double-stranded RNAs induce a pattern-triggered immune signaling pathway in plants. New Phytol. 2016;211(3):1008-19. https://doi.org/10.1111/nph.13944.

Okano Y, Senshu H, Hashimoto M, Neriya Y, Netsu O, Minato N, et al. In planta recognition of a double-stranded RNA synthesis protein complex by a potexviral RNA silencing suppressor. Plant Cell. 2014;26(5):2168-83. https://doi.org/10.1105/tpc.113.120535.

Olspert A, Kamsol K, Sarmiento C, Gerassimenko J, Truve E. Cocksfoot mottle virus coat protein is dispensable for the systemic infection. Virol J. 2014;11:19. https://doi.org/10.1186/1743-422X-11-19.

Orfanidou CG, Mathioudakis MM, Katsarou K, Livieratos I, Katis N, Maliogka VI. Cucurbit chlorotic yellows virus p22 is a suppressor of local RNA silencing. Arch Virol. 2019;164:2747-59. https://doi.org/10.1007/ s00705-019-04391-x.

Pazhouhandeh M, Dieterle M, Marrocco K, Lechner E, Berry B, Brault V, et al. F-box-like domain in the polerovirus protein $\mathrm{PO}$ is required for silencing suppressor function. Proc Nat Acad Sci USA. 2006;103(6):1994-9. https://doi.org/10.1073/pnas.0510784103.

Peng $Y$, van Wersch R, Zhang Y. Convergent and divergent signaling in PAMP-triggered immunity and effector-triggered immunity. Mol Plant Microbe Interact. 2018;31(4):403-9. https://doi.org/10.1094/ MPMI-06-17-0145-CR.

Perez-Canamas M, Hernandez C. Key importance of small RNA binding for the activity of a glycine-tryptophan (GW) motif-containing viral suppressor of RNA silencing. J Biol Chem. 2015;290(5):3106-20. https://doi.org/10. 1074/jbc.M114.593707.

Pollari M, De S, Wang A, Mäkinen K. The potyviral silencing suppressor HCPro recruits and employs host ARGONAUTE1 in pro-viral functions. PLoS Pathog. 2020;16:e1008965. https://doi.org/10.1371/journal.ppat.10089 65.

Poudel B, Wintermantel WM, Cortez AA, Ho T, Khadgi A, Tzanetakis IE. Epidemiology of blackberry yellow vein associated virus. Plant Dis. 2013;97(10):1352-7. https://doi.org/10.1094/PDIS-01-13-0018-RE.
Pumplin N, Voinnet O. RNA silencing suppression by plant pathogens: defence, counter-defence and counter-counter-defence. Nat Rev Microbiol. 2013;11:745-60. https://doi.org/10.1038/nrmicro3120.

Quito-Avila DF, Lightle D, Martin RR. Effect of raspberry bushy dwarf virus, raspberry leaf mottle virus, and raspberry latent virus on plant growth and fruit crumbliness in "meeker" red raspberry. Plant Dis. 2014;98(2):176-83. https://doi.org/10.1094/PDIS-05-13-0562-RE.

Rahim MD, Andika IB, Han C, Kondo H, Tamada T. RNA4-encoded p31 of beet necrotic yellow vein virus is involved in efficient vector transmission, symptom severity and silencing suppression in roots. J Gen Virol. 2007;88(5):1611-9. https://doi.org/10.1099/vir.0.82720-0.

Raikhy G, Hallan V, Kulshrestha S, Sharma ML, Ram R, Zaidi AA. First report of carnation necrotic fleck virus (CNFV) infecting carnations in India. Plant Pathol. 2003;52(6):801. https://doi.org/10.1111/j.1365-3059.2003. 00910.x.

Rajamaki ML, Valkonen JPT. Control of nuclear and nucleolar localization of nuclear inclusion protein a of picorna-like potato virus A in Nicotiana species. Plant Cell. 2009;21(8):2485-502. https://doi.org/10.1105/tpc. 108.064147.

Rawlings RA, Krishnan V, Walter NG. Viral RNAi suppressor reversibly binds siRNA to outcompete Dicer and RISC via multiple turnover. J Mol Biol. 2011;408(2):262-76. https://doi.org/10.1016/j.jmb.2011.02.038.

Reed JC, Kasschau KD, Prokhnevsky Al, Gopinath K, Pogue GP, Carrington $J C$, et al. Suppressor of RNA silencing encoded by beet yellows virus. Virology. 2003;306(2):203-9. https://doi.org/10.1016/S0042-6822(02) 00051-X.

Ren B, Guo Y, Gao F, Zhou P, Wu F, Meng Z, et al. Multiple functions of rice dwarf phytoreovirus Pns 10 in suppressing systemic RNA silencing. J Virol. 2010;84(24):12914-23. https://doi.org/10.1128/JVI.00864-10.

Renovell A, Vives MC, Ruiz-Ruiz S, Navarro L, Moreno P, Guerri J. The citrus leaf blotch virus movement protein acts as silencing suppressor. Virus Genes. 2012;44:131-40. https://doi.org/10.1007/s11262-011-0674-9.

Rodríguez-Negrete E, Lozano-Durán R, Piedra-Aguilera A, Cruzado L, Bejarano ER, Castillo AG. Geminivirus Rep protein interferes with the plant DNA methylation machinery and suppresses transcriptional gene silencing. New Phytol. 2013;199(2):464-75. https://doi.org/10.1111/nph.12286.

Rogers $\mathrm{K}$, Chen X. Biogenesis, turnover, and mode of action of plant microRNAs. Plant Cell. 2013;25(7):2383-99. https://doi.org/10.1105/tpc.113. 113159 .

Rott ME, Jelkmann W. Little cherry virus-2: sequence and genomic organization of an unusual member of the Closteroviridae. Arch Virol. 2005:150:107-23. https://doi.org/10.1007/s00705-004-0382-z.

Rubio L, Guerri J, Moreno P. Genetic variability and evolutionary dynamics of viruses of the family Closteroviridae. Front Microbiol. 2013;4:151. https:// doi.org/10.3389/fmicb.2013.00151.

Ruiz L, Simón A, García C, Velasco L, Janssen D. First natural crossover recombination between two distinct species of the family Closteroviridae leads to the emergence of a new disease. PLOS ONE. 2018;13:e0198228. https://doi.org/10.1371/journal.pone.0198228.

Sabanadzovic S, Ghanem-Sabanadzovic NA, Rowhani A, Grant JA, Uyemoto JK. Detection of cherry virus $\mathrm{A}$, cherry necrotic rusty mottle virus and little cherry virus 1 in California orchards. J Plant Pathol. 2005;87(3):173-7.

Salleh W, Mahfoudhi N, Djelouah K. First report of plum bark necrosis stem pitting-associated virus in stone fruit trees in Tunisia. J Plant Pathol. 2011;93(Suppl):S75

Sanan-Mishra N, Jailani AAK, Mandal B, Mukherjee SK. Secondary siRNAs in plants: biosynthesis, various functions, and applications in virology. Front Plant Sci. 2021;12:610283. https://doi.org/10.3389/fpls.2021. 610283.

Sansregret R, Dufour V, Langlois M, Daayf F, Dunoyer P, Voinnet O, et al. Extreme resistance as a host counter-counter defense against viral suppression of RNA silencing. PLoS Pathog. 2013;9: e1003435. https://doi.org/10. 1371/journal.ppat.1003435.

Sarmiento C, Gomez E, Meier M, Kavanagh TA, Truve E. Cocksfoot mottle virus P1 suppresses RNA silencing in Nicotiana benthamiana and Nicotiana tabacum. Virus Res. 2007;123(1):95-9. https://doi.org/10.1016/j.virusres. 2006.07.013.

Schnettler E, Hemmes H, Huismann R, Goldbach R, Prins M, Kormelink R. Diverging affinity of tospovirus RNA silencing suppressor proteins, NSs, for various RNA duplex molecules. J Virol. 2010;84:11542-54. https://doi. org/10.1128/JVI.00595-10. 
Senshu H, Yamaji Y, Minato N, Shiraishi T, Maejima K, Hashimoto M, et al. A dual strategy for the suppression of host antiviral silencing: two distinct suppressors for viral replication and viral movement encoded by potato virus M. JVirol. 2011;85(19):10269-78. https://doi.org/10.1128/JVI. 05273-11.

Sether DM, Hu JS. Yield impact and spread of pineapple mealybug wilt associated virus-2 and mealybug wilt of pineapple in Hawaii. Plant Dis. 2002;86(8):867-74. https://doi.org/10.1094/PDIS.2002.86.8.867.

Shan L, He P, Li J, Heese A, Peck SC, Nurnberger T, et al. Bacterial effectors target the common signaling partner BAK1 to disrupt multiple MAMP receptor-signaling complexes and impede plant immunity. Cell Host Microbe. 2008;4(1):17-27. https://doi.org/10.1016/j.chom.2008.05.017.

Shao Z-Q, Xue J-Y, Wang Q, Wang B, Chen J-Q. Revisiting the origin of plant NBS-LRR genes. Trends Plant Sci. 2019;24(1):9-12. https://doi.org/10 1016/j.tplants.2018.10.015.

Shen M, Xu Y, Jia R, Zhou X, Ye K. Size-independent and noncooperative recognition of dsRNA by the rice stripe virus RNA silencing suppressor NS3. J Mol Biol. 2010;404(4):665-79. https://doi.org/10.1016/j.jmb.2010.10.007.

Shen WJ, Ruan XL, Li XS, Zhao Q, Li HP. RNA silencing suppressor Pns11 of rice gall dwarf virus induces virus-like symptoms in transgenic rice. Arch Virol. 2012;157:1531-9. https://doi.org/10.1007/s00705-012-1339-2.

Shi Y, Gu M, Fan Z, Hong Y. RNA silencing suppressors: how viruses fight back. Future Virol. 2008;3(2):125-33. https://doi.org/10.2217/17460794.3.2. 125.

Shimura H, Masuta C, Yoshida N, Sueda K, Suzuki M. The 2b protein of asparagus virus 2 functions as an RNA silencing suppressor against systemic silencing to prove functional synteny with related cucumoviruses. Virology. 2013;442(2):180-8. https://doi.org/10.1016/j.virol.2013.04.015.

Shivaprasad PV, Rajeswaran R, Blevins T, Schoelz J, Meins F, Hohn T, et al. The CaMV transactivator/viroplasmin interferes with RDR6-dependent trans-acting and secondary siRNA pathways in Arabidopsis. Nucleic Acids Res. 2008;36(18):5896-909. https://doi.org/10.1093/nar/gkn590.

Silhavy D, Molnár A, Lucioli A, Szittya G, Hornyik C, Tavazza M, et al. A viral protein suppresses RNA silencing and binds silencing-generated, 21- to 25- nucleotide double-stranded RNAs. EMBO J. 2002;21 (12):3070-80. https://doi.org/10.1093/emboj/cdf312.

Sun L, Andika IB, Shen J, Yang D, Ratti C, Chen J. The CUG-initiated larger form coat protein of chinese wheat mosaic virus binds to the cysteine-rich RNA silencing suppressor. Virus Res. 2013;177(1):66-74. https://doi.org/ 10.1016/j.virusres.2013.07.013.

Takeda A, Tsukuda M, Mizumoto H, Okamoto K, Kaido M, Mise K, et al. A plant RNA virus suppresses RNA silencing through viral RNA replication. EMBO J. 2005;24(17):3147-57. https://doi.org/10.1038/sj.emboj.76007 76.

Tan H, Li B, Guo H. The diversity of post-transcriptional gene silencing mediated by small silencing RNAs in plants. Essays Biochem. 2020;64(6):91930. https://doi.org/10.1042/EBC20200006.

Tatineni S, Qu F, Li R, Morris TJ, French R. Triticum mosaic poacevirus enlists P1 rather than HC-Pro to suppress RNA silencing-mediated host defense. Virology. 2012;433(1):104-15. https://doi.org/10.1016/j.virol.2012.07.016.

Te J, Melcher U, Howard A, Verchot-Lubicz J. Soilborne wheat mosaic virus (SBWMV) 19K protein belongs to a class of cysteine rich proteins that suppress RNA silencing. Virol J. 2005;2:18. https://doi.org/10.1186/ 1743-422X-2-18.

Teixeira RM, Ferreira MA, Raimundo GAS, Fontes EPB. Geminiviral triggers and suppressors of plant antiviral immunity. Microorganisms. 2021;9(4):775. https://doi.org/10.3390/microorganisms9040775.

Thekke-Veetil T, Aboughanem-Sabanadzovic N, Keller KE, Martin RR, Sabanadzovic S, Tzanetakis IE. Molecular characterization and population structure of blackberry vein banding associated virus, new ampelovirus associated with yellow vein disease. Virus Res. 2013;178(2):234-40. https://doi.org/10.1016/j.virusres.2013.09.039.

Tilsner J, Linnik O, Wright KM, Bell K, Roberts AG, Lacomme C, et al. The TGB1 movement protein of potato virus $X$ reorganizes actin and endomembranes into the $X$-body, a viral replication factory. Plant Physiol. 2012;158(3):1359-70. https://doi.org/10.1104/pp.111.189605.

Tirnaz S, Batley J. DNA methylation: toward crop disease resistance improvement. Trends Plant Sci. 2019;24(12):1137-50. https://doi.org/10.1016/j. tplants.2019.08.007.

Tong X, Liu SY, Zou JZ, Zhao JJ, Zhu FF, Chai LX, et al. A small peptide inhibits siRNA amplification in plants by mediating autophagic degradation of
SGS3/RDR6 bodies. EMBO J. 2021;40:e108050. https://doi.org/10.15252/ embj.2021108050.

Tzanetakis IE, Martin RR. Strawberry chlorotic fleck disease may be caused by a novel closterovirus. In: Proceedings of XI international symposium on small fruit virus diseases. Acta horticulturae, vol 780. 2008. p. 21-6. https://doi.org/10.17660/ActaHortic.2008.780.2.

Tzanetakis IE, Postman JD, Martin RR. Characterization of a novel member of the family Closteroviridae from Mentha spp. Phytopathology. 2005a:95(9):1043-8. https://doi.org/10.1094/PHYTO-95-1043.

Tzanetakis IE, Postman JD, Martin RR. A member of the Closteroviridae from mint with similarities to all three genera of the family. Plant Dis. 2005b;89(6):654-8. https://doi.org/10.1094/PD-89-0654.

Tzanetakis IE, Wintermantel WM, Cortez AA, Barnes JE, Barrett SM, Bolda $\mathrm{MP}$, et al. Epidemiology of strawberry pallidosis-associated virus and occurrence of pallidosis disease in North America. Plant Dis. 2006;90(10):1343-6. https://doi.org/10.1094/PD-90-1343.

Tzanetakis IE, Halgren A, Mosier N, Martin RR. Identification and characterization of raspberry mottle virus, a novel member of the Closteroviridae. Virus Res. 2007;127(1):26-33. https://doi.org/10.1016/j.virusres.2007.03. 010.

Tzanetakis IE, Wintermantel WM, Poudel B, Zhou J. Diodia vein chlorosis virus is a group-1 crinivirus. Arch Virol. 2011;156:2033-7. https://doi.org/10. 1007/s00705-011-1055-3.

Tzanetakis IE, Martin RR, Wintermantel WM. Epidemiology of criniviruses: an emerging problem in world agriculture. Front Microbiol. 2013;4:119. https://doi.org/10.3389/fmicb.2013.00119.

Valli A, Martin-Hernandez AM, Lopez-Moya JJ, Garcia JA. RNA silencing suppression by a second copy of the $\mathrm{P} 1$ serine protease of cucumber vein yellowing ipomovirus, a member of the family Potyviridae that lacks the cysteine protease HCPro. J Virol. 2006;80:10055-63. https://doi.org/10. 1128/JVI.00985-06.

Varallyay E, Havelda Z. Unrelated viral suppressors of RNA silencing mediate the control of ARGONAUTE1 level. Mol Plant Pathol. 2013;14(6):567-75. https://doi.org/10.1111/mpp.12029.

Varallyay E, Valoczi A, Agyi A, Burgyan J, Havelda Z. Plant virus-mediated induction of miR168 is associated with repression of ARGONAUTE1 accumulation. EMBO J. 2010;29(20):3507-19. https://doi.org/10.1038/ emboj.2010.215.

Vaucheret H. Post-transcriptional small RNA pathways in plants: mechanisms and regulations. Genes Dev. 2006;20:759-71. https://doi.org/10.1101/ gad. 1410506

Vaucheret H. Plant ARGONAUTES. Trends Plant Sci. 2008;13(7):350-8. https:// doi.org/10.1016/j.tplants.2008.04.007.

Vogler H, Akbergenov R, Shivaprasad PV, Dang V, Fasler M, Kwon MO, et al. Modification of small RNAs associated with suppression of RNA silencing by tobamovirus replicase protein. J Virol. 2007;81 (19):10379-88. https://doi.org/10.1128/JVI.00727-07.

Voinnet O. Non-cell autonomous RNA silencing. FEBS Lett. 2005;579(26):585871. https://doi.org/10.1016/j.febslet.2005.09.039.

Voinnet O, Lederer C, Baulcombe DC. A viral movement protein prevents spread of the gene silencing signal in Nicotiana benthamiana. Cell. 2016;166(3):780. https://doi.org/10.1016/j.cell.2016.07.015.

Waheed S, Anwar M, Saleem MA, Wu J, Tayyab M, Hu Z. The critical role of small RNAs in regulating plant innate immunity. Biomolecules. 2021;11(2):184. https://doi.org/10.3390/biom11020184.

Wang LY, Lin SS, Hung TH, Li TK, Lin NC, Shen TL. Multiple domains of the tobacco mosaic virus p126 protein can independently suppress local and systemic RNA silencing. Mol Plant Microbe Interact. 2012;25(5):648-57. https://doi.org/10.1094/MPMI-06-11-0155.

Wang Y, Dang M, Hou H, Mei Y, Qian Y, Zhou X. Identification of an RNA silencing suppressor encoded by a mastrevirus. J Gen Virol. 2014;95(9):20828. https://doi.org/10.1099/vir.0.064246-0.

Wang F, Qi S, Gao Z, Akinyemi IA, Xu D, Zhou B. Complete genome sequence of tobacco virus 1, a closterovirus from Nicotiana tabacum. Arch Virol. 2016a;161:1087-90. https://doi.org/10.1007/s00705-015-2739-x.

Wang J, Zhu D, Tan Y, Zong X, Wei H, Hammond RW, et al. Complete nucleotide sequence of little cherry virus 1 (LChV-1) infecting sweet cherry in China. Arch Virol. 2016b;161:749-53. https://doi.org/10.1007/ s00705-015-2737-z. 
Wang B, Yang X, Wang Y, Xie Y, Zhou X. Tomato yellow leaf curl virus V2 interacts with host histone deacetylase 6 to suppress methylation-mediated transcriptional gene silencing in plants. J Virol. 2018;92:e00036-18.

Wang X, Luo C, Xu Y, Zhang C, Bao M, Dou J, et al. Expression of the p24 silencing suppressor of grapevine leafroll-associated virus 2 from potato virus $X$ or barley stripe mosaic virus vector elicits hypersensitive responses in Nicotiana benthamiana. Plant Physiol Biochem. 2019;142:34-42. https:// doi.org/10.1016/j.plaphy.2019.06.033.

Wang Y, Gong Q, Wu Y, Huang F, Ismayil A, Zhang D, et al. A calmodulin-binding transcription factor links calcium signaling to antiviral RNAi defense in plants. Cell Host Microbe. 2021;29(9):1393-406. https://doi.org/10. 1016/j.chom.2021.07.003.

Waterhouse PM, Helliwell CA. Exploring plant genomes by RNA-induced gene silencing. Nat Rev Gen. 2003;4:29-38. https://doi.org/10.1038/nrg982.

Wintermantel WM. Co-infection of beet mosaic virus with beet yellowing viruses leads to increased symptom expression on sugar beet. Plant Dis. 2005;89(3):325-31. https://doi.org/10.1094/PD-89-0325.

Wintermantel WM, Hladky LL, Gulati-Sakhuja A, Li R, Liu HY, Tzanetakis IE. The complete nucleotide sequence and genome organization of tomato infectious chlorosis virus: a distinct crinivirus most closely related to lettuce infectious yellows virus. Arch Virol. 2009;154:1335-41. https:// doi.org/10.1007/s00705-009-0432-7.

Wu J, Du Z, Wang C, Cai L, Hu M, Lin Q, et al. Identification of Pns6, a putative movement protein of RRSV, as a silencing suppressor. Virol J. 2010;7:335. https://doi.org/10.1186/1743-422X-7-335.

Wu J, Wang C, Du Z, Cai L, Hu M, Wu Z, et al. Identification of Pns12 as the second silencing suppressor of rice gall dwarf virus. Sci China Life Sci. 2011;54:201-8. https://doi.org/10.1007/s11427-011-4142-5.

Wu WQ, Fan HY, Jiang N, Wang Y, Zhang ZY, Zhang YL, et al. Infection of beet necrotic yellow vein virus with RNA4-encoded p31 specifically upregulates pathogenesis-related protein 10 in Nicotiana benthamiana. Virol J. 2014;11:118. https://doi.org/10.1186/1743-422X-11-118.

Yaegashi H, Takahashi T, Isogai M, Kobori T, Ohki S, Yoshikawa N. Apple chlorotic leaf spot virus $50 \mathrm{kDa}$ movement protein acts as a suppressor of systemic silencing without interfering with local silencing in Nicotiana benthamiana. J Gen Virol. 2007;88(1):316-24. https://doi.org/10.1099/ vir.0.82377-0.

Yang Z, Li Y. Dissection of RNAi-based antiviral immunity in plants. Curr Opin Virol. 2018;32:88-99. https://doi.org/10.1016/j.coviro.2018.08.003.

Yang X, Xie Y, Raja P, Li S, Wolf JN, Shen Q, et al. Suppression of methylationmediated transcriptional gene silencing by $\beta C 1-S A H H$ protein interaction during geminivirus-betasatellite infection. PLoS Pathog. 2011;7:e1002329. https://doi.org/10.1371/journal.ppat.1002329.

Ye K, Patel DJ. RNA silencing suppressor p21 of beet yellows virus forms an RNA binding octameric ring structure. Structure. 2005;13(9):1375-84. https://doi.org/10.1016/j.str.2005.06.017.

Yelina NE, Savenkov El, Solovyev AG, Morozov SY, Valkonen JP. Long-distance movement, virulence, and RNA silencing suppression controlled by a single protein in hordei- and potyviruses: complementary functions between virus families. J Virol. 2002;76(24):12981-91. https://doi.org/10. 1128/JVI.76.24.12981-12991.2002.
Young BA, Stenger DC, Qu F, Morris TJ, Tatineni S, French R. Tritimovirus P1 functions as a suppressor of RNA silencing and an enhancer of disease symptoms. Virus Res. 2012;163(2):672-7. https://doi.org/10.1016/j.virus res.2011.12.019.

Yu B, Chapman EJ, Yang Z, Carrington JC, Chen X. Transgenically expressed viral RNA silencing suppressors interfere with microRNA methylation in Arabidopsis. FEBS Lett. 2006;580(13):3117-20. https://doi.org/10.1016/j. febslet.2006.04.063.

Yu H, Qi S, Chang Z, Rong Q, Akinyemi IA, Wu Q. Complete genome sequence of a novel velarivirus infecting areca palm in China. Arch Virol. 2015;160:2367-70. https://doi.org/10.1007/s00705-015-2489-9.

Zhai J, Jeong DH, De Paoli ED, Park S, Rosen BD, LiY, et al. MicroRNAs as master regulators of the plant NB-LRR defense gene family via the production of phased, trans-acting siRNAs. Genes Dev. 2011;25:2540-53. https:// doi.org/10.1101/gad.177527.111.

Zhang X, Yuan YR, Pei Y, Lin SS, TuschI T, Patel DJ, et al. Cucumber mosaic virus-encoded $2 \mathrm{~b}$ suppressor inhibits Arabidopsis Argonaute1 cleavage activity to counter plant defense. Genes Dev. 2006;20:3255-68. https:// doi.org/10.1101/gad.1495506.

Zhang X, Du P, Lu L, Xiao Q, Wang W, Cao X, et al. Contrasting effects of HC-Pro and $2 b$ viral suppressors from sugarcane mosaic virus and tomato aspermy cucumovirus on the accumulation of siRNAs. Virology. 2008;374(2):351-60. https://doi.org/10.1016/j.virol.2007.12.045.

Zhang C, Wu Z, Li Y, Wu J. Biogenesis, function, and applications of virusderived small RNAs in plants. Front Microbiol. 2015;6:1237. https://doi. org/10.3389/fmicb.2015.01237.

Zhao S, Li Y. Current understanding of the interplays between host hormones and plant viral infections. PLoS Pathog. 2021;17:e1009242. https://doi. org/10.1371/journal.ppat.1009242.

Zhao RN, Wang R, Wang N, Fan ZF, Zhou T, Shi YC, Chai M. First report of tomato chlorosis virus in China. Plant Dis. 2013;97(8):1123. https://doi. org/10.1094/PDIS-12-12-1163-PDN.

Zhao F, Yoo RH, Lim S, Igori D, Lee SH, Moon JS. Nucleotide sequence and genome organization of a new proposed crinivirus, tetterwort vein chlorosis virus. Arch Virol. 2015;160:2899-902. https://doi.org/10.1007/ s00705-015-2552-6.

Zhao R, Wang N, Liu S, Ling K, Fan Z, Zhou T. P22 of tomato chlorosis virus, an RNA silencing suppressor, is naturally expressed in the infected plant. Acta Virol. 2016;60(4):423-5. https://doi.org/10.4149/av_2016_04_423.

Zhou ZS, Dell'Orco M, Saldarelli P, Turturo C, Minafra A, Martelli GP. Identification of an RNA-silencing suppressor in the genome of grapevine virus A. J Gen Virol. 2006:87(8):2387-95. https://doi.org/10.1099/vir.0.81893-0.

Zrachya A, Glick E, Levy Y, Arazi T, Citovsky V, Gafni Y. Suppressor of RNA silencing encoded by tomato yellow leaf curl virus-Israel. Virology. 2007;358(1):159-65. https://doi.org/10.1016/j.virol.2006.08.016.

\section{Publisher's Note}

Springer Nature remains neutral with regard to jurisdictional claims in published maps and institutional affiliations.

\footnotetext{
Ready to submit your research? Choose BMC and benefit from:

- fast, convenient online submission

- thorough peer review by experienced researchers in your field

- rapid publication on acceptance

- support for research data, including large and complex data types

- gold Open Access which fosters wider collaboration and increased citations

- maximum visibility for your research: over $100 \mathrm{M}$ website views per year
}

At BMC, research is always in progress.

Learn more biomedcentral.com/submissions 